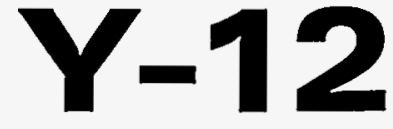

\section{OAK RIDGE \\ $Y-12$ \\ PLANT}

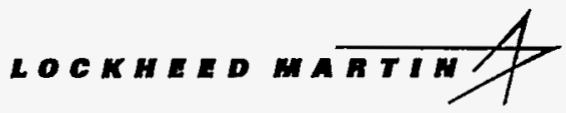

NMTNITITIYY OF THIS DOCUMENT IS UNLLMTED

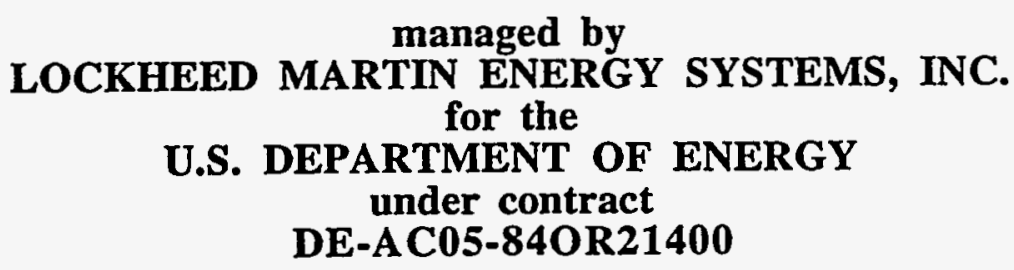

\section{POROSITY DEVELOPMENT IN THE COPPER RIDGE DOLOMITE AND \\ MAYNARDVILLE LIMESTONE, BEAR CREEK VALLEY AND CHESTNUT RIDGE, TENNESSEE}

P. M. Goldstrand

L. S. Menefee

R. B. Dreier

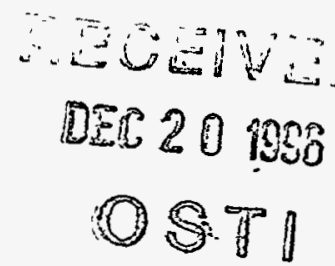

December 1995

Prepared for the

Environmental Management Department

Health, Safety, Environment, and Accountability

Organization

Oak Ridge Y-12 Plant

Oak Ridge, Tennessee 38731

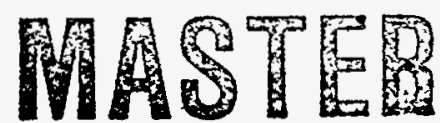

MANAGED BY

LOCKHEED MARTIN ENERGY SYSTEMS, INC.

R21400 


\section{DISCLAIMER}

This report was prepared as an account of work sponsored by an agency of the United States Government. Neither the United States Government nor any agency thereof, nor any of their employees, makes any warranty, express or implied, or assumes any legal liability or responsibility for the accuracy, completeness, or usefulness of any information, apparatus, product, or process disclosed, or represents that its use would not infringe privately owned rights. Reference herein to any specific commercial product, process, or service by trade name, trademark, manufacturer, or otherwise, does not necessarily constitute or imply its endorsement, recommendation, or favoring by the United States Government or any agency thereof. The views and opinions of authors expressed herein do not necessarily state or reflect those of the United States Government or any agency thereof. 


\title{
POROSITY DEVELOPMENT IN THE COPPER RIDGE DOLOMITE AND MAYNARDVILLE LIMESTONE, BEAR CREEK VALLEY AND CHESTNUT RIDGE, TENNESSEE
}

\author{
Prepared by: \\ P. M. Goldstrand(1), L. S. Menefee(2), R. B. Dreier(3) \\ Prepared for the \\ Environmental Management Department \\ Health, Safety, Environment, and Accountability Organization \\ Oak Ridge Y-12 Plant \\ Oak Ridge, Tennessee 37831 \\ managed by \\ LOCKHEED MARTIN ENERGY SYSTEMS, INC. \\ for the \\ U.S. DEPARTMENT OF ENERGY \\ under contract DE-AC05-84OR21400
}

(1) Geology Department, University of Nevada, Reno, NV
(2) Department of Geology, Appalachian State University, Boone, NC
(3) Environmental Sciences Division, Oak Ridge National Laboratory, Oak Ridge, TN 


\section{DISCLAMMER}

Portions of this document may be illegible in electronic image products. Images are produced from the best available original document. 
Section Page

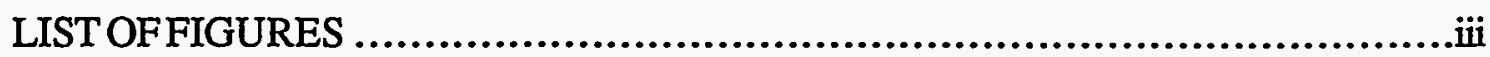

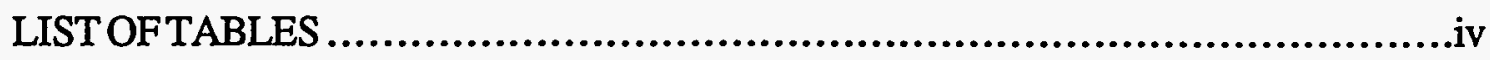

EXECUTIVE SUMMARY ....................................................... v

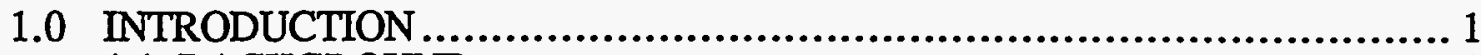

1.1 BACKGROUND ............................................................ 1

1.2 GENERAL GEOLOGY AND HYDROGEOLOGY OF

BEAR CREEK VALLEY........................................................... 1

1.2.1 Nolichucky Shale........................................................... 2

1.2.2 Maynardville Limestone ................................................. 2

1.2.3 Copper Ridge Dolomite............................................................. 4

1.2 .4 Hydrology ................................................................... 5

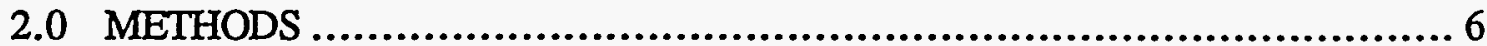

2.1 POROSITY DETERMINATION ........................................... 6

2.2 DENSITY DETERMINATION.................................................... 7

2.3 PETROGRAPHIC ANALYSIS ....................................... 7

3.0 POROSITY WITHIN THE COPPER RIDGE DOLOMITE

AND MAYNARDVILLE LIMESTONE ...................................... 8

3.1 MAYNARDVILLE LIMESTONE POROSITIES ......................... 8

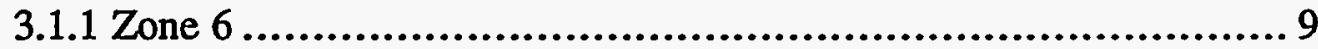

3.1.2 Zone 5 ....................................................................... 10

3.1.3 Zone 4 ..................................................................10

3.1.4 Zone 3 .......................................................... 10

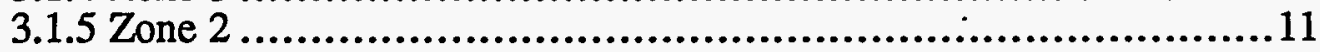

3.2 COPPER RIDGE DOLOMITE POROSITIES ............................11

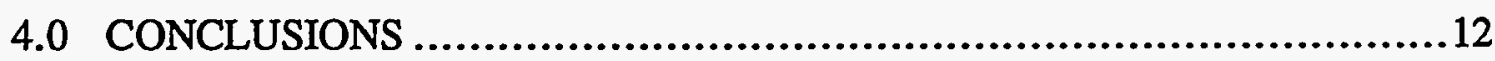

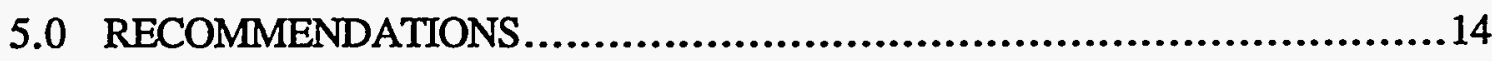

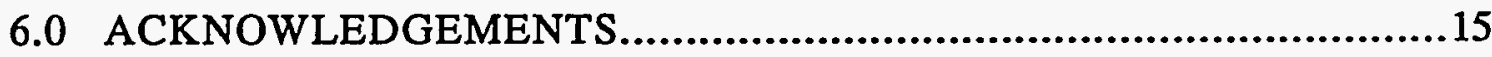

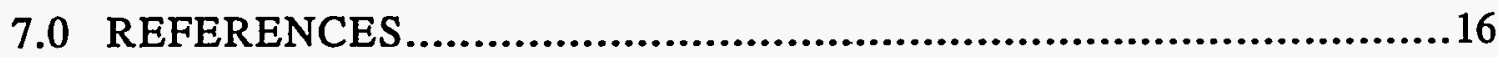

APPENDIX A - Volumetric Porosity Data ............................................34

APPENDIX B - Carbonate Rock Densities from Core GW-722 ......................42

APPENDIX C - Petrographic Analyses for the Maynardville Limestone .................43 


\section{LIST OF FIGURES}

Figure.

1.1 Generalized location and geologic map of the Oak Ridge area, Tennessee

1.2 Generalized geologic map of Bear Creek Valley,

Oak Ridge, Tennessee

1.3 Natural gamma-ray log and lithologic column of Maynardville

Limestone in Bear Creek Valley

3.1 Matrix porosities with respect to depth in Well GW-130

3.2 Matrix porosities with respect to depth in Well GW-135

3.3 Matrix porosities with respect to depth in Well GW-137

3.4 Matrix porosities with respect to depth in Well GW-138

3.5 Matrix porosities with respect to depth in Well GW-722

3.6 Matrix porosities with respect to depth in Zone 6 of the Maynardville Limestone.

3.7 Matrix porosities with respect to depth in Zone 5 of the Maynardville Limestone.

3.8 Matrix porosities with respect to depth in Zone 4 of the Maynardville Limestone

3.9 Matrix porosities with respect to depth in Zone 3 of the Maynardville Limestone.

3.10 Matrix porosities with respect to depth in Zone 2 of the Maynardville Limestone.

5.1 Mean porosities of carbonate rock samples from GW-135 and GW-138 at varying time intervals in a vacuum 


\section{LIST OF TABLES}

Table

Page

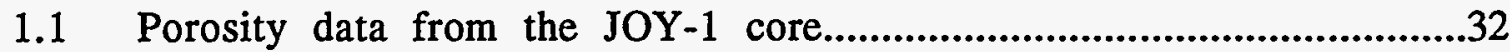

3.1 Mean matrix porosities for the Maynardville Limestone and Copper Ridge Dolomite. 


\section{EXECUTIVE SUMMARY}

Matrix porosity data from deep core obtained in Bear Creek Valley indicate that porosities in the Maynardville Limestone are lithology and depth dependent. Matrix porosities are greater in the Copper Ridge Dolomite than in the Maynardville Limestone, yet there is no apparent correlation with depth. Two interrelated diagenetic processes are the major controlling factors on porosity development in the Copper Ridge Dolomite and Maynardville Limestone; dissolution of evaporate minerals and dedolomitization. Both of these diagenetic processes produce matrix porosities between 2.1 and 1.3 percent in the Copper Ridge Dolomite and upper part of the Maynardville Limestone (Zone 6) to depths of approximately $600 \mathrm{ft}$ bgs. Mean matrix porosities in Zones 5 through 2 of the Maynardville Limestone range from 0.8 to 0.5 percent.

A large number of cavities have been intersected during drilling activities in nearly all zones of the Maynardville Limestone in Bear Creek Valley. Therefore, any Maynardville Limestone zone within approximately $200 \mathrm{ft}$ of the ground surface is likely to contain cavities that allow significant and rapid flow of groundwater. Zone 6 could be an important stratigraphic unit in the Maynardville Limestone for groundwater flow and contaminant transport because of the abundance of vuggy and moldic porosities. There are large variations in the thickness and lithology in the lower part of the Maynardville (Zones 2, 3, and 4 in the Burial Grounds region). The direction and velocity of strike-parallel groundwater flow may be altered in this area within the lower Maynardville Limestone. 


\section{INTRODUCTION}

\subsection{BACKGROUND}

The Department of Energy's Oak Ridge Y-12 Plant (Fig. 1.1), located in Bear Creek Valley (BCV), contains several hazardous and nonhazardous waste sites and underground storage tank sites within the valley and adjacent Chestnut Ridge (CR) that have the potential of contaminating local surface streams and groundwater. To accurately model the affects of matrix diffusion on contaminant transport and evaluate groundwater contamination and migration from these sites, information pertaining to the range of bedrock porosities (both fracture and matrix porosity) are needed. However, there is sparse data pertaining to bedrock porosity throughout the Oak Ridge Reservation (ORR). Prior to this report, bedrock matrix porosity data were only available from 10 samples collected from the JOY-1 core (Table 1.1; de Laguna and others 1968). Additionally, the JOY-1 core is from the Copper Creek thrust sheet and provides no data on the Copper Ridge Dolomite or Maynardville Limestone.

Matrix porosity data for the Copper Ridge Dolomite and Maynardville Limestone within BCV and CR, which are considered part of the Knox aquifer (Solomon et al., 1992), are discussed in this report (Appendix A). Fracture porosity was not part of this study and is not addressed in this report. Additionally, this report provides data on the affects of lithology and depth on porosity and the diagenetic evolution with respect to secondary porosity. Bulk rock density data from the Maynardville Limestone are also provided from GW-722 (Fig. 1.2; Appendix B).

\subsection{GENERAL GEOLOGY AND HYDROGEOLOGY OF BEAR CREEK VALLEY}

Chestnut Ridge and BCV are located in the upper plate of the Whiteoak Mountain thrust fault within the Valley and Ridge province of the southern Appalachian fold and thrust belt, East Tennessee. The bedrock of BCV and adjacent ridges consists of Cambrian and 
Ordovician carbonate and clastic sedimentary rocks (King and Hasse 1987; Hatcher et al., 1992). The majority of the waste management areas within BCV are located in the

Nolichucky Shale and the Maynardville Limestone. Bedrock strike in the area varies locally from $N 47^{\circ} \mathrm{E}$ to $\mathrm{N} 67^{\circ} \mathrm{E}$ and dips average $45^{\circ}$ to the southeast (King and Hasse 1987). The Nolichucky Shale forms the central floor of BCV and is gradationally overlain by the Maynardville Limestone. The Maynardville Limestone forms the southeastern floor of BCV and is gradationally overlain by the ridge-forming Copper Ridge Dolomite.

\subsubsection{Nolichucky Shale}

The Nolichucky Shale ranges in stratigraphic thickness from 508 to $604 \mathrm{ft}$ in BCV (Hatcher et al., 1992). The formation consists of purple-brown to green-gray, massive to very thinly bedded shale intrastratified with light-gray, thin- to medium-bedded limestone and rare calcareous siltstone. The limestones commonly are conglomeratic and oolitic (Weber 1988; Foreman et al., 1991). Because of the lack of fresh core from the Nolichucky Shale, no porosity data were collected from this unit during this study.

\subsubsection{Maynardville Limestone}

The overlying Maynardville Limestone ranges in stratigraphic thickness from 383 to $450 \mathrm{ft}$ in BCV (Hatcher et al., 1992; Shevenell et al., 1992). Based on gamma-ray log signatures, the uppermost Nolichucky, Maynardville Limestone, and Maynardville-Copper Ridge Dolomite transition have been divided into six zones (Fig.1.3). Zone 1 comprises the upper part of the Nolichucky Shale and was not analyzed. Zones 2 through 6 comprise the Maynardville Limestone. The Copper Ridge Dolomite is not subdivided in this report.

The contact between the Nolichucky Shale and Maynardville Limestone is geophysically placed immediately above the highest right.deflection on the gamma-ray log and at the bottom of the comparatively constant carbonate baseline (Hatcher et al., 1992). Lithologically, this contact can be either abrupt or gradational. Where the contact is gradational, the contact is placed where the limestone to shale ratio becomes $>50$ percent within the ribbon-bedded lime mudstone below the lowermost massive limestone.

Zone 2 ranges in downhole thickness from 0 to $236 \mathrm{ft}$ ( 0 to $173 \mathrm{ft}$ stratigraphic 
thickness; Shevenell et al., 1992; Goldstrand 1995). Near the Burial Grounds Waste Management area, the downhole thickness of Zone 2 changes by approximately $200 \mathrm{ft}$ over a horizontal distance of approximately $500 \mathrm{ft}$ (Goldstrand 1995).

Zone 2 is dominantly composed of thrombolitic (non-laminated algal) limestone and dolomitic limestone, which has a diagnostic mottled and clotted appearance of light and darkgray with abundant thin, wispy shale and carbonate mudstone stringers and partings (Goldstrand 1995). Very-fine to fine crystalline limestone is light-gray and dolomitic mudstone is dark-gray. Beds are massive- to thickly bedded boundstone, packstone, and grainstone. Interbeds of bioclastic, peloidal, oolitic, stromatolitic, and oncolitic limestone are common. Zone 2 is commonly stylolitic and burrowed, and small, open and calcitefilled vugs and fractures are also common. Locally, pyrite is either associated with shale stringers or is dispersed throughout the thrombolitic limestone.

The average downhole thickness of Zone 3 is $74 \mathrm{ft}$ (54 ft stratigraphic thickness; Shevenell et al., 1992). As with Zone 2, Zone 3 thins and, in places, is absent near the Burial Grounds (Goldstrand 1995). Where Zone 3 is absent, a hybrid of zones 4 and 3 (Subzone 4/3) is present (Goldstrand 1995). The base of Zone 3 is gradational with Zone 2 and interbeds of thrombolitic and oolitic limestones, matrix-supported carbonate conglomerate, carbonate mudstone, and stringers of calcareous shale are common. Thick beds of carbonate conglomerate (commonly of dolostone clasts) occur within either a shale or coarsely-crystalline limestone matrix. Interbeds of peloidal and oncolitic packstone and grainstone are common. Oolitic beds are light- to medium-gray; thrombolitic beds are mottled medium- to dark-gray, and fine- to medium-grained. The upper parts of Zone 3 consist of oncolitic and oolitic limestone, thick interbeds of digitate stromatolitic limestone and dark-gray, slightly dolomitic mudstone. Black shale interbeds and stringers are more common within the peloidal and oolitic limestone beds. Stylolites with black, clay residue and disseminated pyrite are common.

Zone 4 has a downhole thickness of approximately $106 \mathrm{ft}$ with an average stratigraphic thickness of $78 \mathrm{ft}$ (Shevenell et al., 1992). Generally, Zone 4 thickens to the east and west in the study area and thins and grades into subzone $4 / 3$ in the area of the Burial Grounds. Zone 4 consists of light- to dark-gray, medium- to coarsely-crystalline 
limestone and minor dolostone. Interbeds of oolitic, digitate stromatolitic, and algal laminated limestones occur near the base. Interbeds of oncolitic dolomitic limestone and limestone occur in the upper part of this zone. Stromatolitic and bioclastic limestone beds are common. Calcite-filled birds-eye structures, gypsum-and anhydrite-filled vugs, and stylolites are also present.

Within the Burial Grounds area, gamma-ray signatures below Zone 5 generally do not compare with either Zone 4 or 3 , but rather appear to be a combination of both zones; hence in the Burial Grounds area, this zone is referred to as subzone $4 / 3$ (Goldstrand in press). In general, the relatively flat baseline of subzone $4 / 3$ suggests that it is more closely related to Zone 4 than Zone 3. Lithologically, subzone $4 / 3$ consists mostly of thrombolitic and stromatolitic limestone with interbeds of oolitic limestone.

Zone 5 has an average downhole thickness of $54 \mathrm{ft}$ and a stratigraphic thickness of 39 $\mathrm{ft}$ (Shevenell et al., 1992). Most of Zone 5 consists of wavy-to-even, thickly bedded, lightgray oolitic, peloidal, and oncolitic packstone and grainstone (Goldstrand 1995). Very-thin interbeds and stringers of dark-green to gray calcareous shale and carbonate mudstone are characteristic of this zone. Thin intraformational conglomerate beds are associated with the shale and mudstone beds.

The average downhole thickness for Zone 6 is $100 \mathrm{ft}$ with a calculated stratigraphic thickness of $73 \mathrm{ft}$ (Shevenell et al., 1992). Zone 6 consists dominantly of mottled, tan to dark-gray dolostone and slightly calcareous dolostone. Generally, this zone is medium-to coarsely-crystalline with a saccharoidal texture, massive to well-laminated, and stromatolitic. Algal laminated rip-up clasts, bioturbation, and birds-eye structures are common. Stylolites, open and filled (calcite and gypsum) vugs and veins are common. The abundance of vugs is characteristic of this zone.

\subsubsection{Copper Ridge Dolomite}

The Maynardville Limestone-Copper Ridge Dolomite contact is gradational with mottled, irregularly bedded, tan to light-brown dolomitic limestone within the uppermost Maynardville grading upward into cherty dolostone of the Copper Ridge. Dark- to mediumgray, medium- to coarse-grained, massively bedded dolostone with abundant vugs dominate 
the lower one-half of Copper Ridge Dolomite. Saccharoidal texture is common in the lower part of the Copper Ridge. Stromatolites, oolites, thin shale interbeds, and birds-eye structures are abundant in the lower part of this formation. The upper one-half consists of medium- to light-gray, fine- to medium-grained cherty dolostone. The upper part of Copper Ridge Dolomite is also stromatolitic with interbeds of intraformational conglomerate, and small vugs are common. The Copper Ridge Dolomite ranges in thickness from 244 to 335 meters (Hatcher et al., 1992).

\subsubsection{Hydrology}

Within BCV a shallow groundwater and surface water divide is located near the northwest end of the Y-12 Plant (Geraghty and Miller Inc. 1987). Northeast of the divide, groundwater flows toward Upper East Fork Poplar Creek and southwest of the divide, the groundwater flow is toward Bear Creek (Geraghty and Miller Inc. 1990). The surface water in BCV and groundwater in the Maynardville Limestone are interconnected, with springs discharging from the Maynardville Limestone into Bear Creek (Geraghty and Miller Inc. 1985). Also, a large number of solution cavities are present in the Maynardville Limestone underlying Bear Creek (Shevenell et al., 1992). Hydraulic head data indicate convergent flow into the Maynardville Limestone, suggesting that the Maynardville Limestone acts as a hydraulic drain for BCV (Dreier et al., 1993).

The Copper Ridge Dolomite forms the northwestern part of $\mathrm{CR}$. The potentiometric surface reflects a subdued version of the surface topography, resulting in a groundwater divide at the crest of CR. Within the Copper Ridge Dolomite and overlying soil, on the northwestern part of $\mathrm{CR}$, the hydraulic gradient is high in response to the steep topographic slope from the ridge to $\mathrm{BCV}$. 


\section{METHODS}

\subsection{POROSITY DETERMINATION}

Porosity analyses were conducted on carbonate rock samples from five cores; GW-130, GW-135, GW-137, GW-138, and GW-722 (Fig. 1.2). Volumetric porosity measurement procedures were as follows:

1) Three replicates were collected from a random sampling interval and dried at $105^{\circ} \mathrm{C}$ for one hour to drive off the water in the pore spaces, but not the water of hydration in minerals.

2) Samples were placed in a desiccator and allowed to cool for 0.5 hour.

3) The dry sample was weighed to an accuracy of $0.01 \mathrm{~g}$.

4) The samples were then saturated by water immersion in a vacuum for 0.5 hour, with periodic agitation to remove trapped air.

5) Excess water was removed and the weight of the saturated samples were measured to an accuracy of $0.01 \mathrm{~g}$.

6) The porosity was calculated as follows:

Porosity $=$ (pore volume $/$ total volume) $\times 100$

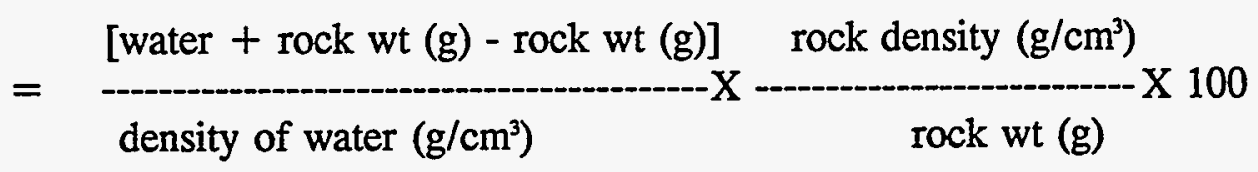

where:

density of water is assumed $1 \mathrm{~g} / \mathrm{cm}^{3}$ and the average density of rockforming minerals is $2.65 \mathrm{~g} / \mathrm{cm}^{3}$. Bulk rock density analysis (Appendix B) from carbonate lithologies in GW-722 have a mean density of 2.66 , suggesting that the average density of 2.65 used to calculate porosity values in this report are reasonable for all samples.

Individual results for the three replicates per sampling interval, together with the mean and one standard deviation are reported in Appendix A. 


\subsection{DENSITY DETERMINATION}

Bulk rock density measurements were conducted on the carbonate lithologies from 45 intervals in core GW-722 (Appendix B). Density was calculated as:

bulk density $=\frac{\text { mass of sample }(\mathrm{g})}{\text { bulk sample volume }\left(\mathrm{cm}^{3}\right)}$

where the bulk sample volume was calculated using the water displacement method (Brown 1981); the amount of water displaced by a saturated-submerged sample. Mass was determine on saturated rock samples.

\subsection{PETROGRAPHIC ANALYSIS}

Petrographic analysis of 27 thin-sections from wells GW-135, GW-137, and GW-138 were used to interpret the diagenetic history of the Maynardville Limestone. Half of each thin-section was stained for calcium carbonate and analyzed under a petrographic microscope. Three hundred point counts per thin-section were completed to determine the percentage of different mineral species and void spaces, and these data are summarized in Appendix C. 


\section{POROSITY WITHIN THE COPPER RIDGE DOLOMITE AND MAYNARDVILLE}

\section{LIMESTONE}

Following the definitions of Choquette and Pray (1970), primary porosity is considered to be that porosity present in the rock after final deposition and secondary porosity is any post-depositional porosity created within the rock. Petrographic analysis indicates occlusion of all primary porosity has occurred through cementation and that most, if not all, the porosity present in the Maynardville Limestone and Copper Ridge Dolomite at this time is secondary or post-depositional in origin.

\subsection{MAYNARDVILLE LIMESTONE POROSITIES}

Volumetric porosity data provide an estimate of the microporosity for the Maynardville Limestone zones with respect to depth (Table 3.1; Appendix A). These data indicate that Zone 6 has the highest porosity, followed by Zone 5 , and with zones 4,3 , and 2 being nearly equal (Table 3.1). Porosities generally decrease with respect to depth in all the Maynardville zones (Figs. 3.1 to 3.5).

Core inspection and petrographic analysis provided the most important clues into the controls on secondary porosity in the Maynardville Limestone. The major lithologic controls on the development of secondary porosity are, in order of importance: 1) dissolution of evaporite minerals (gypsum and anhydrite), 2) dedolomitization, 3) carbonate grain size, and 4) oxidation of iron sulfide minerals (pyrite).

Dissolution of gypsum and anhydrite nodules is responsible for the development of vuggy porosity within the upper part of the Maynardville Limestone and throughout the Copper Ridge Dolomite. Nodules of gypsum and anhydrite are preserved in deeper core in the Maynardville Limestone (e.g., GW-135, $1178 \mathrm{ft}$ bgs). At shallow depths, vugs and cavities the size and shape of these nodules are lined with euhedral calcite crystals, suggesting the dissolution of the evaporate minerals and later precipitation of calcite within the void (Saunders and Toran 1994; Goldstrand 1995). Petrographic analysis of gypsum- 
filled vugs from well GW-722 at $523 \mathrm{ft}$ bgs indicate partial dissolution of the gypsum had occurred but that precipitation of calcite has occluded some of that secondary porosity. Additional enlargement of the these vugs has occurred through the dissolution of dolomite crystals related to dedolomitization.

Dedolomitization (replacement of dolomite by calcite) is chemically related to the dissolution of gypsum within the Maynardville Limestone and Copper Ridge Dolomite (Saunders and Toran 1994; Goldstrand 1995) and is an important factor in microporosity development in the dolomitic parts of these formations. Ferroan dolomite is abundant throughout the Copper Ridge Dolomite and upper Maynardville Limestone, and relatively common throughout the middle and lower Maynardville. The ferroan dolomite may have developed during burial diagenesis, replacing original fine-grained carbonate lithologies. In core, generally shallower than $600 \mathrm{ft}$ bgs, ferroan dolomite has been preferentially dissolved with respect to the surrounding carbonate lithologies. In some cases, replacement by calcite pseudomorphs after dolomite has occurred, but generally dissolution of the dolomite crystals has produced moldic micropores.

Carbonate mud appears to favor dissolution in several of the Maynardville Limestone zones. Similar results have been obtained in other studies (Rauch and White 1970; Dreiss 1984), which indicate that smaller carbonate grain-sizes provide a larger surface area for active dissolution by groundwater undersaturated with $\mathrm{CaCO}_{3}$.

Locally, oxidation of pyrite is also responsible for the development of secondary porosity. The transformation has been the oxidation of pyrite to hematite and eventually, formation of moldic porosity.

\subsubsection{Zone 6}

The mean matrix porosity of Zone 6 is 2.1 percent, but mean porosities exceed 7 percent in GW-138 at a depth of approximately $500 \mathrm{ft}$ (Fig. 3.6; Table 3.1). Vuggy and fenestral porosity are abundant in Zone 6 to a depth of $800 \mathrm{ft}$ bgs. Lithologically, Zone 6 consists mostly of stromatolitic dolostone and calcareous dolostone. The predominate cause for the vuggy porosity in this zone is the dissolution of gypsum nodules (leaving abundant vugs up to several $\mathrm{cm}$ long). Also of importance to the development of secondary porosity is 
dedolomitization. Selective dissolution of dolomite crystals (moldic porosity) has created abundant interconnected micropores (generally less than $0.5 \mathrm{~mm}$ in diameter). The processes of gypsum dissolution and dedolomitization are related (Back et al., 1983; Saunders and Toran 1994) and are probably the major cause of porosity development in this zone. Fenestral porosity has also developed due to dissolution of carbonate mud within the dolomite. The stromatolitic dolomites are coarse-grained with intercalated carbonate mud, which originally was trapped between the algal structures and filaments responsible for forming the stromatolites. Dissolution of the intervening carbonate mud produces small (several $\mathrm{mm}$ diameter) elongate vugs.

\subsubsection{Zone 5}

Matrix porosities for Zone 5 range between 0.3 and 2.3 percent, with a mean porosity for the zone of 0.8 percent (Fig. 3.7; Table 3.1). This zone consists generally of coarselycrystalline oolitic packstone and grainstone with interbeds of shale. Moldic porosity is present and developed by the dissolution of dolomite crystals that have replaced ooids (dedolomitization). Dissolution of carbonate mudstone is also common.

\subsubsection{Zone 4}

Zone 4 has a mean matrix porosity of 0.5 percent with porosity values ranging from 0.1 to 1.1 percent (Fig. 3.8; Table 3.1). Many of the lithologies present in Zone 6 are also present in Zone 4. In particular, core intervals with vuggy porosity within Zone 4 occur mostly in stromatolitic dolomitic limestones. As with Zone 6, dedolomitization is responsible for the vuggy and moldic porosity in Zone 4.

\subsubsection{Zone 3}

Porosities in Zone 3 range between 0.1 and 2.2 percent, with a mean matrix porosity of 0.6 percent (Fig. 3.9; Table 3.1). Fenestral solution porosity is associated with stromatolitic and thrombolitic interbeds in which the intervening carbonate muds have dissolved. 


\subsubsection{Zone 2}

Within Zone 2, a large number of solution cavities and vugs, as deep as $1200 \mathrm{ft}$ bgs, are present, but the mean matrix porosity is 0.5 percent (Fig. 3.10; Table 3.1). Much of Zone 2 consists of thrombolitic limestone, with dissolution concentrated in the intercalated carbonate mud (creating vugs) or along the wispy carbonate mud stringer (creating thin, elongate solution zones). Elongate solution zones also occur along the interface between shale stringers and carbonate lithologies, and are probably related to dissolution as groundwater moves along the shale-carbonate interface. Oxidation of pyrite was observed in Zone 2, producing moldic porosity ( $<0.5 \mathrm{~mm}$ in diameter). Stratabound alteration zones caused by groundwater flow along particular beds account for very localized high porosities up to 4.0 percent (e.g., GW-130 at $302 \mathrm{ft}$ ).

\subsection{COPPER RIDGE DOLOMTTE POROSITIES}

Two cores (GW-135 and GW-138) were analyzed for porosity within the Copper Ridge Dolomite and suggest a mean matrix porosity of 1.3 percent (Table 3.1; Appendix A). The mean porosity for the Copper Ridge Dolomite from GW-135 is slightly higher (1.4 percent) than that of GW-138 (1.1 percent). Matrix porosities range up to 8.1 percent in GW-135 and as much as 5.7 percent in GW-138. There is no apparent decrease in porosity with depth in the Copper Ridge Dolomite core (Figs 3.2 and 3.4) as is observed in the Maynardville Limestone.

The majority of the matrix porosity in the Copper Ridge Dolomite is related to dedolomitization which has produced moldic porosity. Fenestral, micro- to- mesopores are common within the stromatolitic dolostones, and are related to dissolution of fine-grained lamination. Vugs, abundant throughout the formation, are a product of dissolution of finegrained carbonate interbeds and evaporate nodules. 


\section{CONCLUSIONS}

Matrix porosity data from deep core drilled in BCV indicate that porosities in the Maynardville Limestone are lithologically and depth dependent. Although matrix porosities are greater in the Copper Ridge Dolomite than the Marynardville Limestone there is no apparent correlation with depth. Two interrelated diagenetic processes are the major controlling factors on porosity development in the Copper Ridge Dolomite and Maynardville Limestone: dissolution of evaporate minerals and dedolomitization. Both these diagenetic processes produce matrix porosities of between 2.1 and 1.3 percent in the Copper Ridge and upper part of the Maynardville to depths of approximately $600 \mathrm{ft}$ bgs. A possible reason there is not a decrease in porosity in the Copper Ridge is that it is almost completely composed of dolostone and that dedolomitization has equally affected the entire formation. The microporosity formed by dedolomitization may also explain the decrease in porosity stratigraphically lower in the Maynardville Limestone. The upper part of the Maynardville Limestone (Zone 6) has the highest porosities and consists mostly of dolostone and dolomitic limestone, whereas the middle and lower parts of the formation (Zone 5 through 2) are mostly limestone. Dedolomitization within the dolomitic part of the Maynardville has produced relatively high matrix porosities but had little affect in the limestone lithologies.

Mean matrix porosities in Zones 5 through 2 of the Maynardville Limestone range from 0.8 to 0.5 percent. Although, moldic porosity related to dedolomitization is locally common (e.g., dolomitized ooids in Zone 5), much of the porosity is related to dissolution of carbonate mud interbeds. Dissolution of intra-algal carbonate mud lithologies produce thin, elongate solution zones or fenestral porosity. Oxidation of pyrite also produces moldic porosity but is only of minor importance in parts of Zone 2 located above approximately $200 \mathrm{ft}$ bgs.

A large number of cavities have been intersected during drilling activities in nearly all

zones of the Maynardville Limestone in BCV (see Shevenell et al., 1992). Therefore, any of the Maynardville zones within approximately $200 \mathrm{ft}$ of the ground surface are likely to contain cavities which allow rapid groundwater flow and contaminant transport (Goldstrand 
and Shevenell 1994). Zone 6 could be an important stratigraphic unit in the Maynardville Limestone for groundwater flow and contaminant transport because of the abundance of vuggy and moldic porosities. There are large variations in the thickness and lithology in the lower part of the Maynardville (Zones 2, 3, and 4 in the Burial Grounds region). The direction and velocity of strike-parallel groundwater flow may be altered in this area within the lower Maynardville Limestone. 


\section{RECOMMENDATIONS}

To accurately model matrix diffusion and evaluate groundwater contamination and migration on the ORR more information pertaining to the range of bedrock porosities is needed. The data provided in this report should be considered preliminary. Additional porosity data are needed from different formations and lithologies (carbonate and siliciclastic) throughout the ORR. Data should be collected from freshly drilled core and more precise methods should be applied (such as mercury displacement techniques).

The volumetric porosity method used in the study is a relatively inexpensive, quick, and nonhazardous method of measuring rock porosities. However, it should be noted that the matrix porosities presented in this report are considered minimum porosities. In the method used to determine porosities in this report (Brown 1981), samples were saturated by water immersion in a vacuum for 30 minutes. Experiments were conducted on samples placed in a vacuum for varying lengths of time $(0.5,0.75,1.0,1.5,2.0$, and 3.0 hours). Mean porosities increased as the length of time in the vacuum increased, reaching equilibrium at about 2 hours (Fig. 5.1). Porosities increased approximately 80 percent between 0.5 hours and 2.0 hours. If this method is to be used for porosity determinations in the future, it is recommended that the samples be saturated by water immersion in a vacuum for no less than 2.0 hours. 


\section{ACKNOWLEDGEMENTS}

The authors would like to thank Peter Lemiszki, Lisa Shevenell, and Kevin Jago for reviewing this report. We wish to thank Peter Lemiszki for helping obtain the equipment used during this study. 


\section{REFERENCES}

Back, W., B.B. Hanshaw, L.N. Plummer, P.H. Rahn, C.T. Rightmire, and M. Rubin.,

"Process and Rate of Dedolomitization: Mass Transfer and ${ }^{14} \mathrm{C}$ dating in a Regional

Carbonate Aquifer". Geological Society of America, v. 94, p. 1415-1429, 1983.

Brown, E.T., (ed), "Rock Charaterization Testing and Monitoring". Pergamon press, New York, p. 81-89, 1981.

Choquette, P.W., and L.C. Pray, "Geologic Nomenclature and Classification of Porosity in

Sedimentary Carbonates". The American Association of Petroleum Geologists

Bulletin, v. 54, No. 2, p. 207-250. 1970.

de Laguna, W.T., T. Tamura, H.O. Weeren, E.G. Struxness, W.C. McClain, and R.C.

Sexton, Engineering Development of Hydraulic Fracturing as a Method for Permanent

Disposal of Radioactive Wastes. Oak Ridge National Laboratory-4259, 1968.

Dreier, R.B., T.O. Early, and H.L. King. Results and Interpretation of Groundwater data obtained from Multiport-Instrumented Coreholes (GW-131 through GW-135), fiscal years 1990 and 1991. Y/TS-803. Oak Ridge Y-12 Plant, 1993.

Dreiss, S.J. "Effects of Lithology on Solution Development in Carbonate Aquifers". Journal of Hydrology. v. 70, p. 295-308. 1984.

Foreman, J.L., K.R. Walker, L.J. Weber, S.G. Driese, and R.B. Dreier. " Slope and Basinal Carbonate Deposition in the Nolichucky Formation (Upper Cambrian) East Tennessee: Effect of Carbonate Suppression by Siliciclastic Deposition on BasinMargin Lithologies". Society of Economic Paleontologists and Mineralogists Core Workshop on Mixed Carbonate-Siliciclastic Sequences. SEPM core Workshop No. 15, Dallas, p. 511-539, 1991.

Geraghty and Miller, Inc., Remedial Alternative for Bear Creek Valley Waste Disposal

Area. Y/SUB/85-00206C/3. Oak Ridge Y-12 Plant, 1985.

Geraghty and Miller, Inc., Monitor-Well Documentation Report for the 1987 Drilling

Program at the Y-12 Plant. Y/SUB/87-00206C/20. Oak Ridge Y-12 Plant, 1987.

Geraghty and Miller, Inc., Comprehensive Groundwater Monitoring Plan for the Oak

Ridge Y-12 Plant. Y/SUB/90-002066C/5, Oak Ridge Y-12 Plant, 1990. 
Goldstrand, P.M, Stratigraphic Variations and Secondary Porosity within the Maynardville Limestone in Bear Creek Valley, Y-12 Plant. Y/TS-1093. 1995.

Goldstrand, P.M., and L.A. Shevenell. "Lithologic Controls on Karst Development and Groundwater Flow in the Copper Ridge Dolomite and Maynardville Limestone, Oak Ridge, Tennessee". Geological Society of America abstractsand programs. p. A-204. 1994.

Hatcher, R.D, Jr, P.L. Lemiszki, R.B. Dreier, R.H., Ketelle, R.R. Lee, D.A. Lietzke, W.M. McMaster, J.L. Foreman, and S.Y. Lee. Status Report on the Geology of the Oak Ridge Reservation. ORNL/TM-12074. 1992.

King, H.L. and C.S. Haase. Subsurface-Controlled Geological maps for the Y-12 Plant and Adjacent Areas of Bear Creek Valley. ORNL/TM-10112. Oak Ridge National Laboratory, 1987.

Raugh, H.W., and W.B. White. "Lithologic Controls on the Development of Solution Porosity in Carbonate Aquifers". Water Resources Research. v. 6, p. 1175-1192. 1970.

Saunders, J.A. and L.E. Toran, "Evidence for Dedolomitization and Mixing in Paleozoic Carbonates near Oak Ridge, Tennessee". Ground Water, 1994.

Shevenell, L.A., R.B. Dreier and W.K. Jago. Summary of Fiscal Years 1991 and 1992 Construction, Hydrologic, and Geological Data Obtained from the Maynardville Limestone Exit Pathway Monitoring Program. Y/TS-814. Oak Ridge Y-12 Plant, 1992.

Weber, L.J., Jr. "Paleoenvironmental Analysis and Test of Stratigraphic Cyclicity in the Nolichucky Shale and Maynardville Limestone (Upper Cambrian) in Central East Tennessee". Ph.D. dissertation. University of Tennessee, Knoxville. 389 p., 1988. 


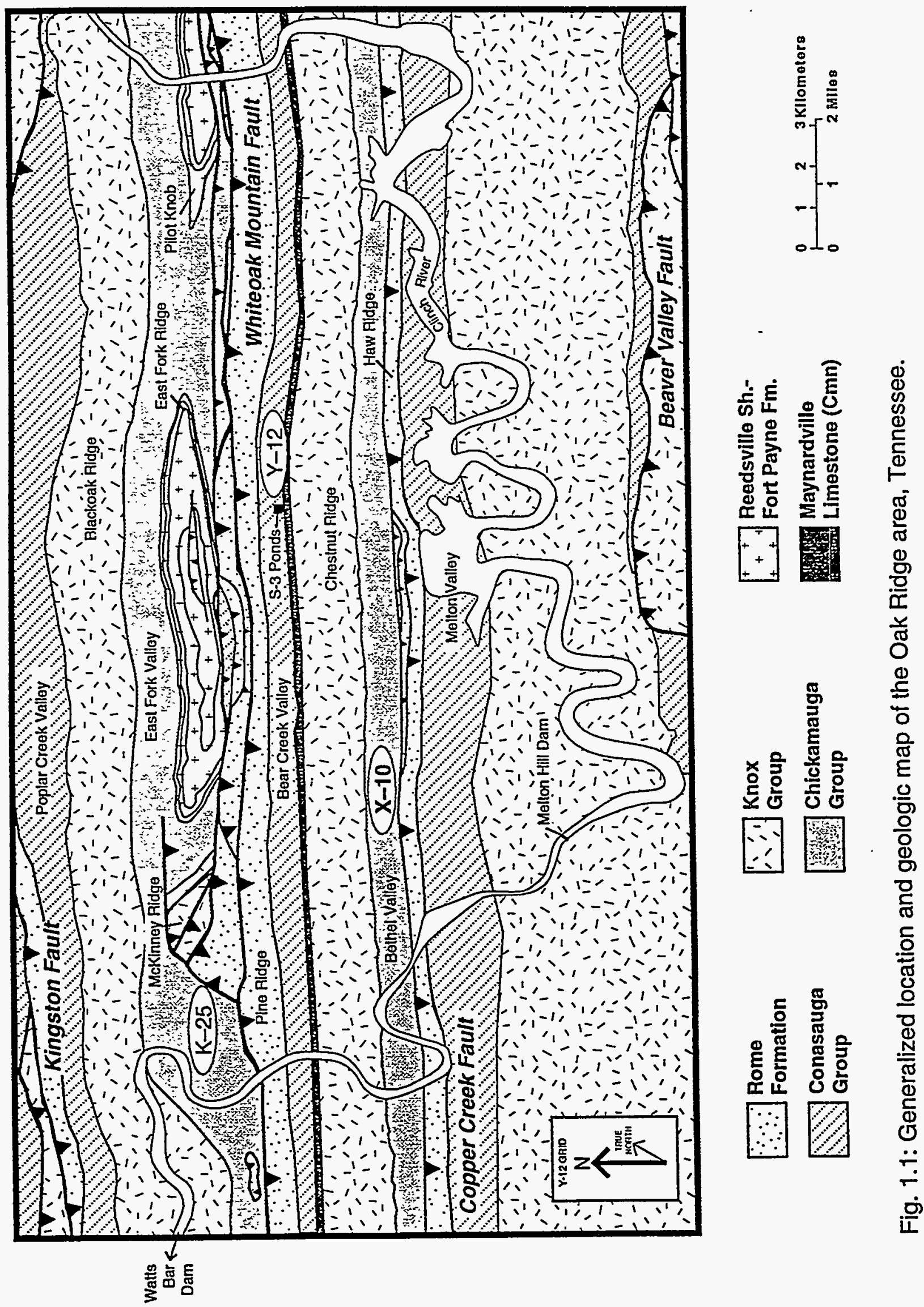




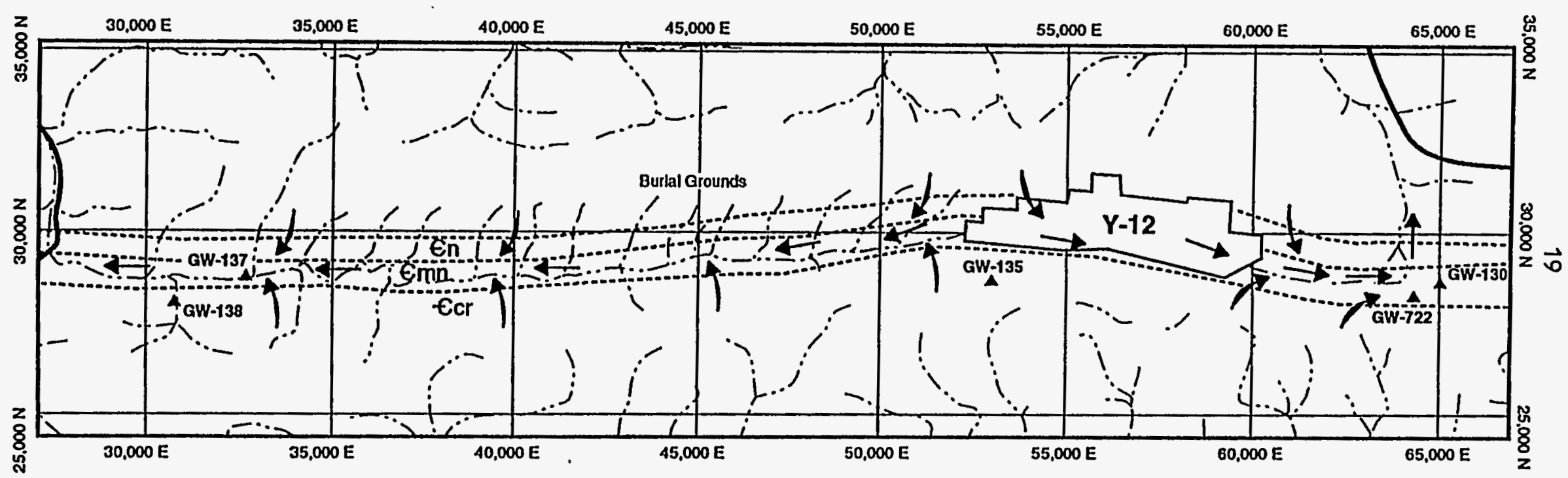

Fig. 1.2: Generalized geologic map of Bear Creek Valley, Oak Ridge, Tennessee (showing well locations and approximate formation contacts for the Copper Ridge Dolomite (Ccr), Maynardville Limestone ( $\mathrm{Cmn}$ ), and Nolichucky Shale (Cn). Arrows denote general shallow bedrock groundwater flow directions). 


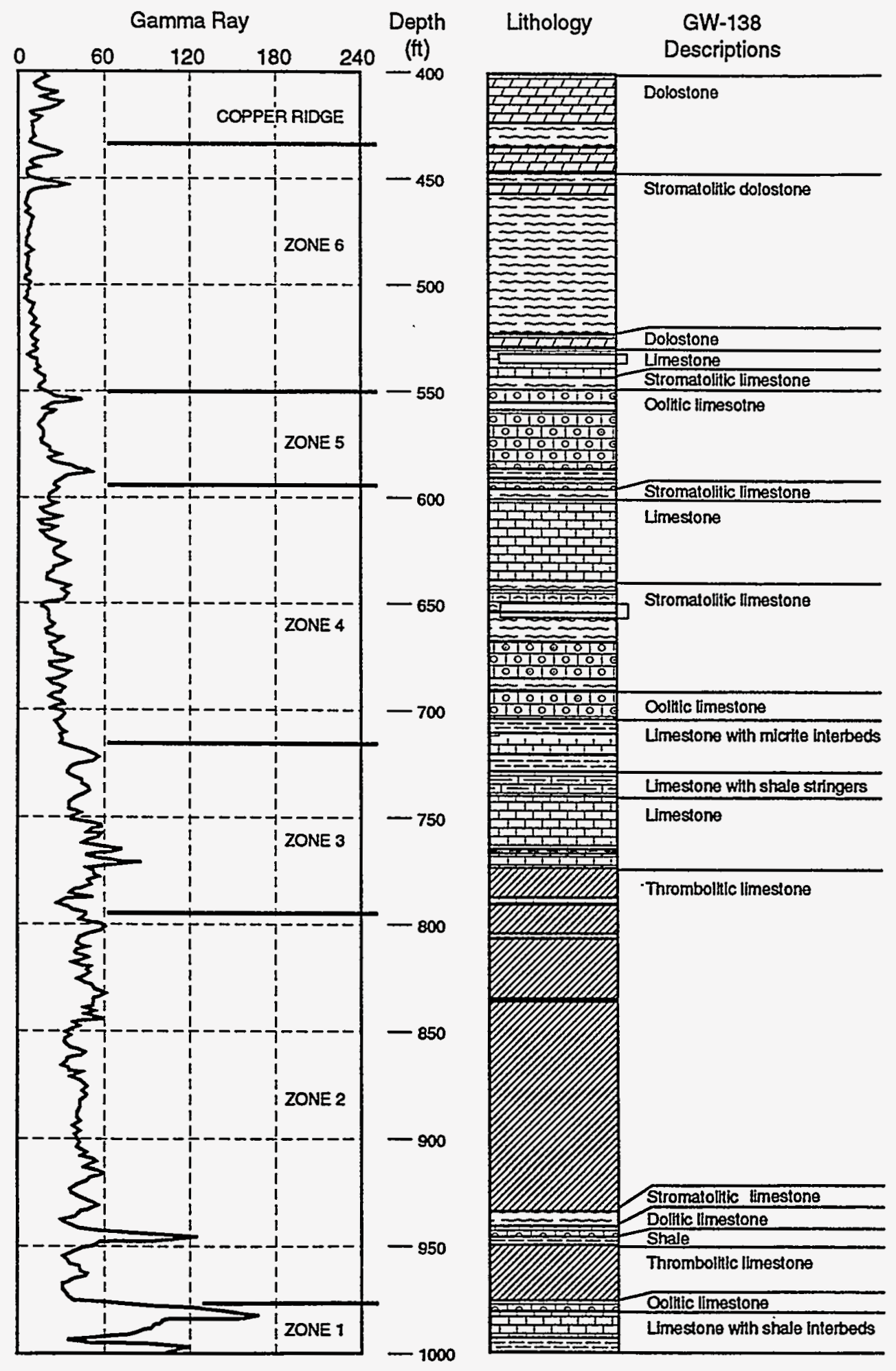

Fig. 1.3: Natural gamma-ray log and lithologic column of Maynardville Limestone in Bear Creek Valley: 
Well GW-130

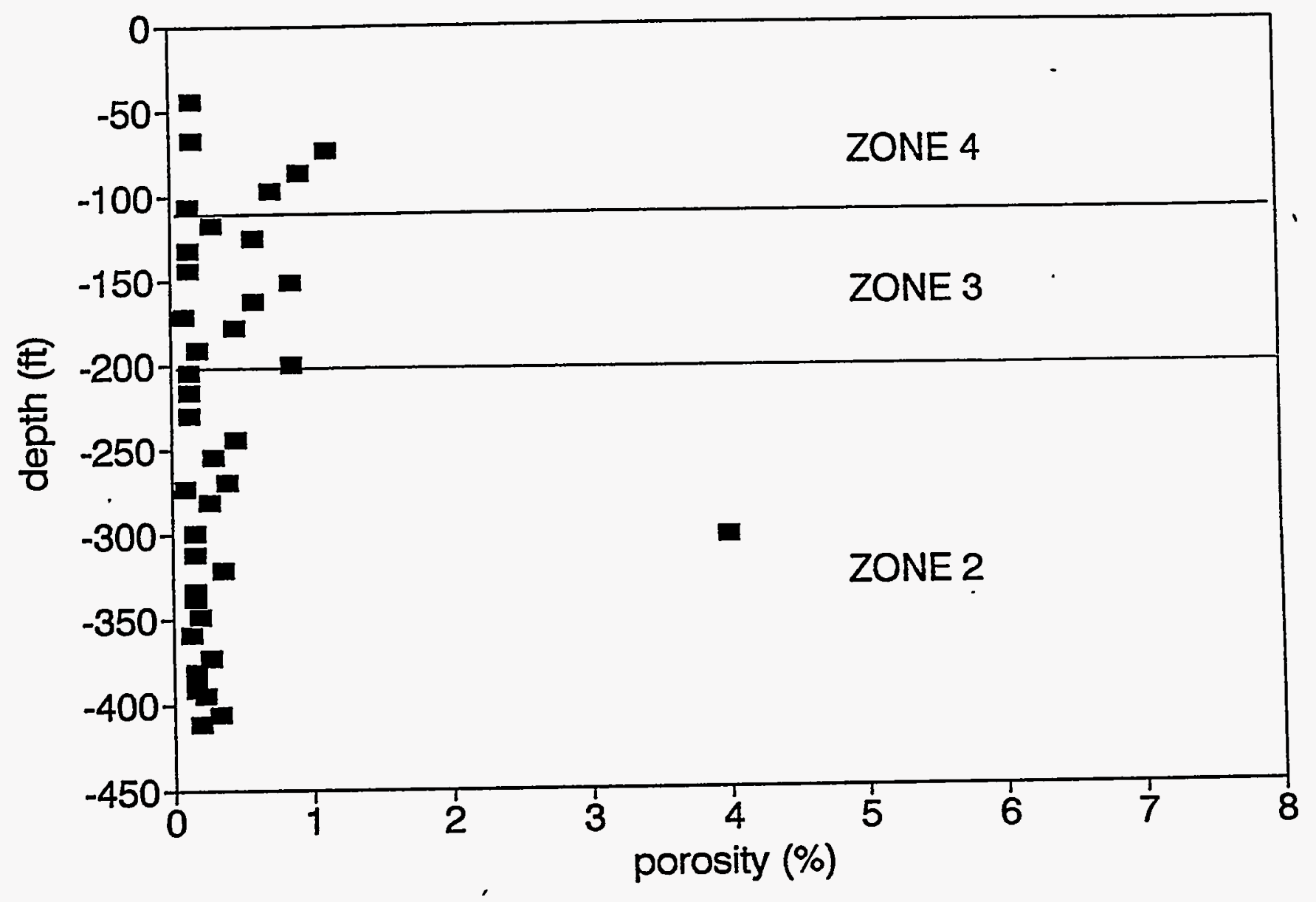

Fig. 3.1: Matrix porosities with respect to depth in Well GW-130. 


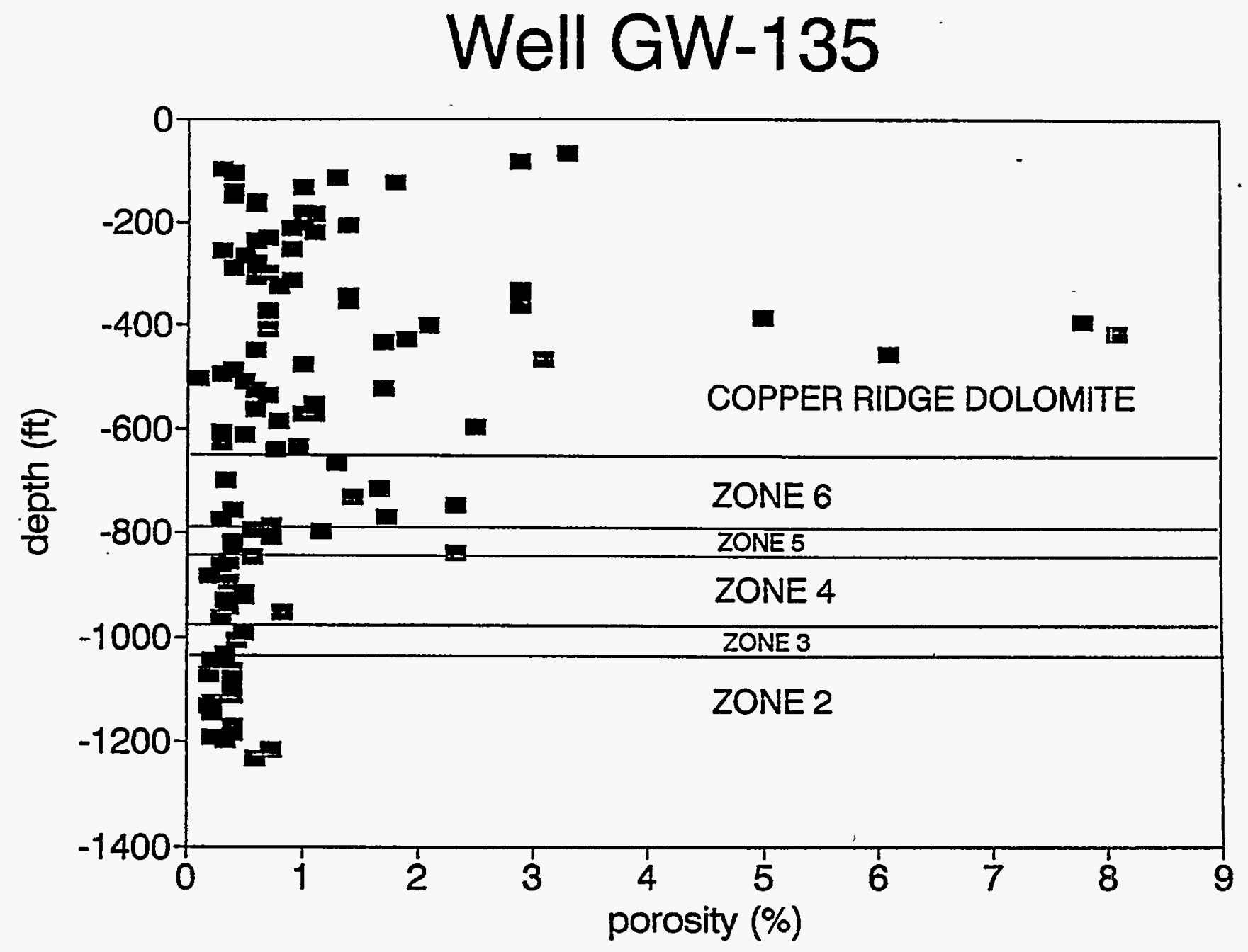

Fig 3.2: Matrix porosities with respect to depth in Well GW-135. 
Well GW-137

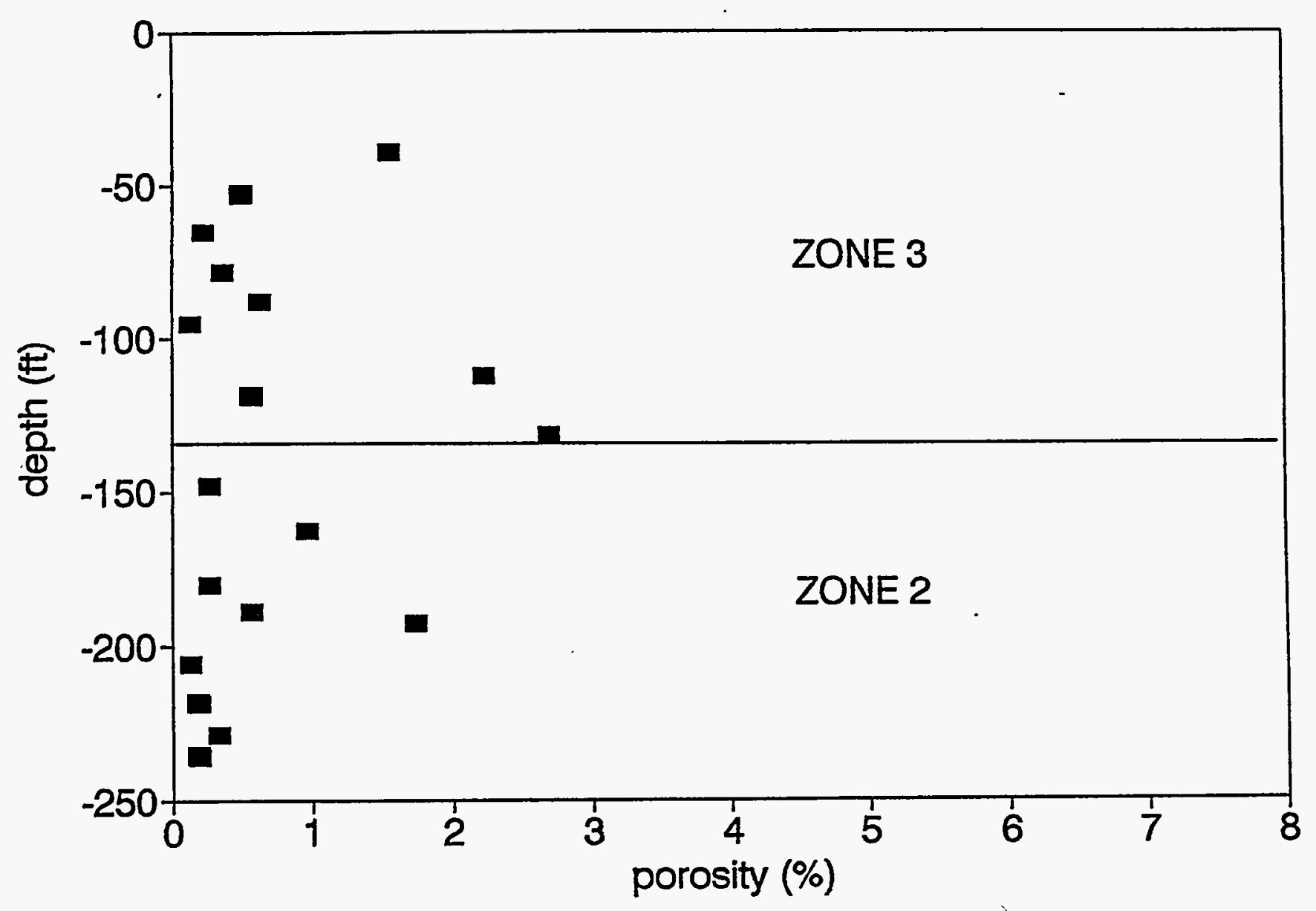

Fig. 3.3: Matrix porosities with respect to depth in Well GW-137. 
Well GW-138

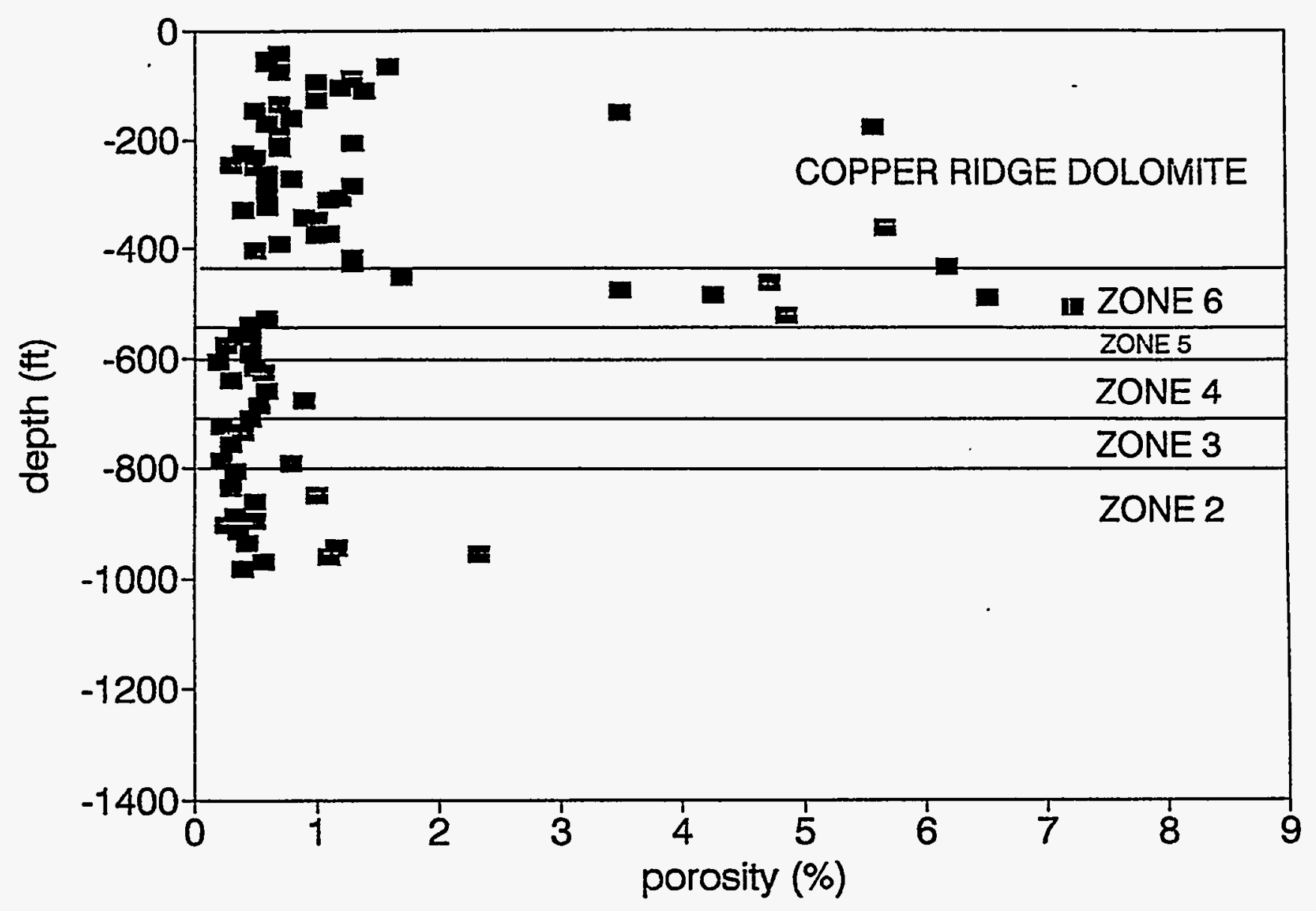

Fig 3.4: Matrix porosities with respect to depth in Well GW-138. 
Well GW-722

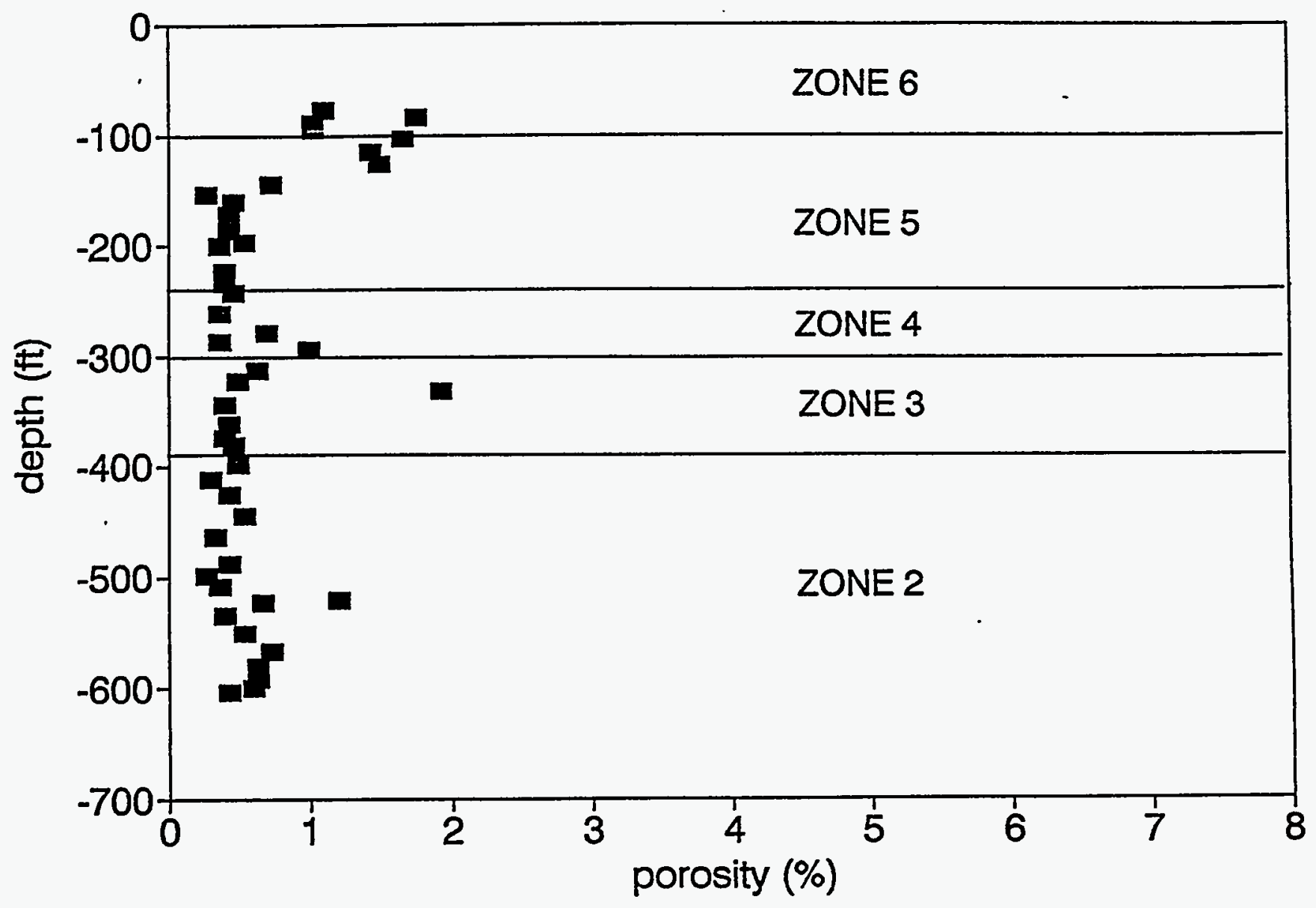

Fig 3.5: Matrix porosities with respect to depth in Well GW-722. 


\section{ZONE 6}

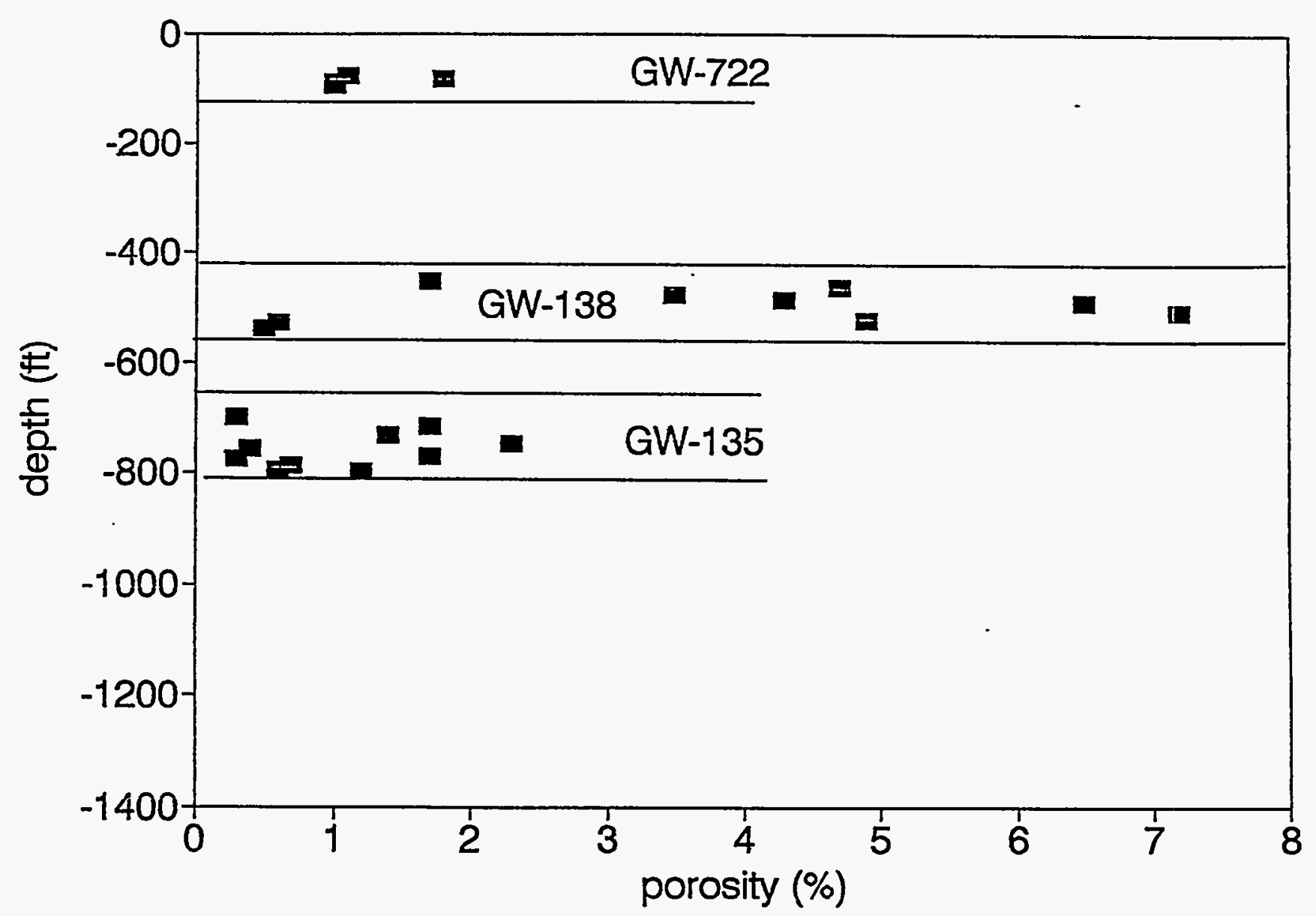

Fig. 3.6: Matrix porosities with respect to depth in Zone 6 of the Maynardville Limestone. 
ZONE 5

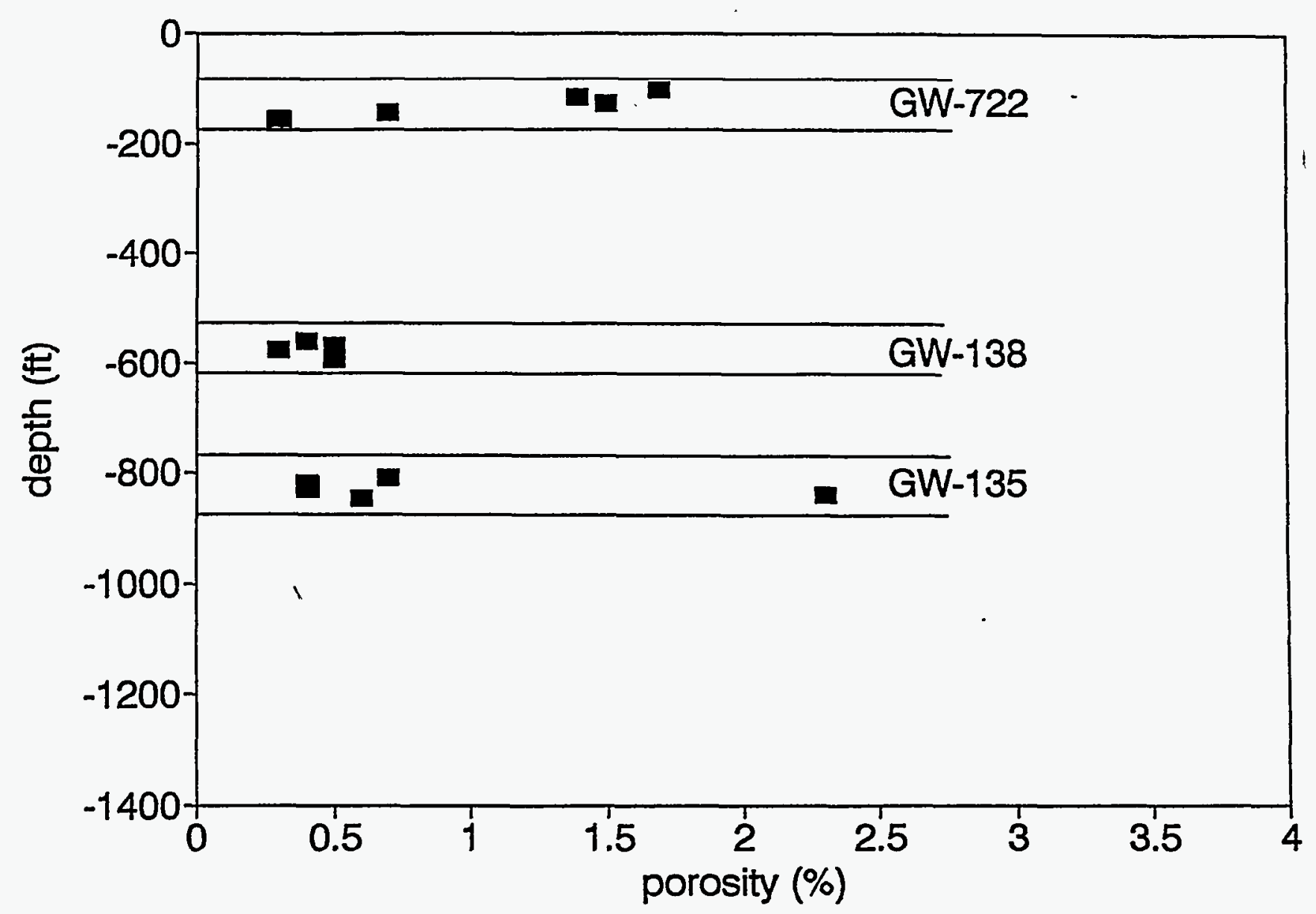

Fig. 3.7: Matrix porosities with respect to depth in Zone 5 of the Maynardville Limestone. 
ZONE 4

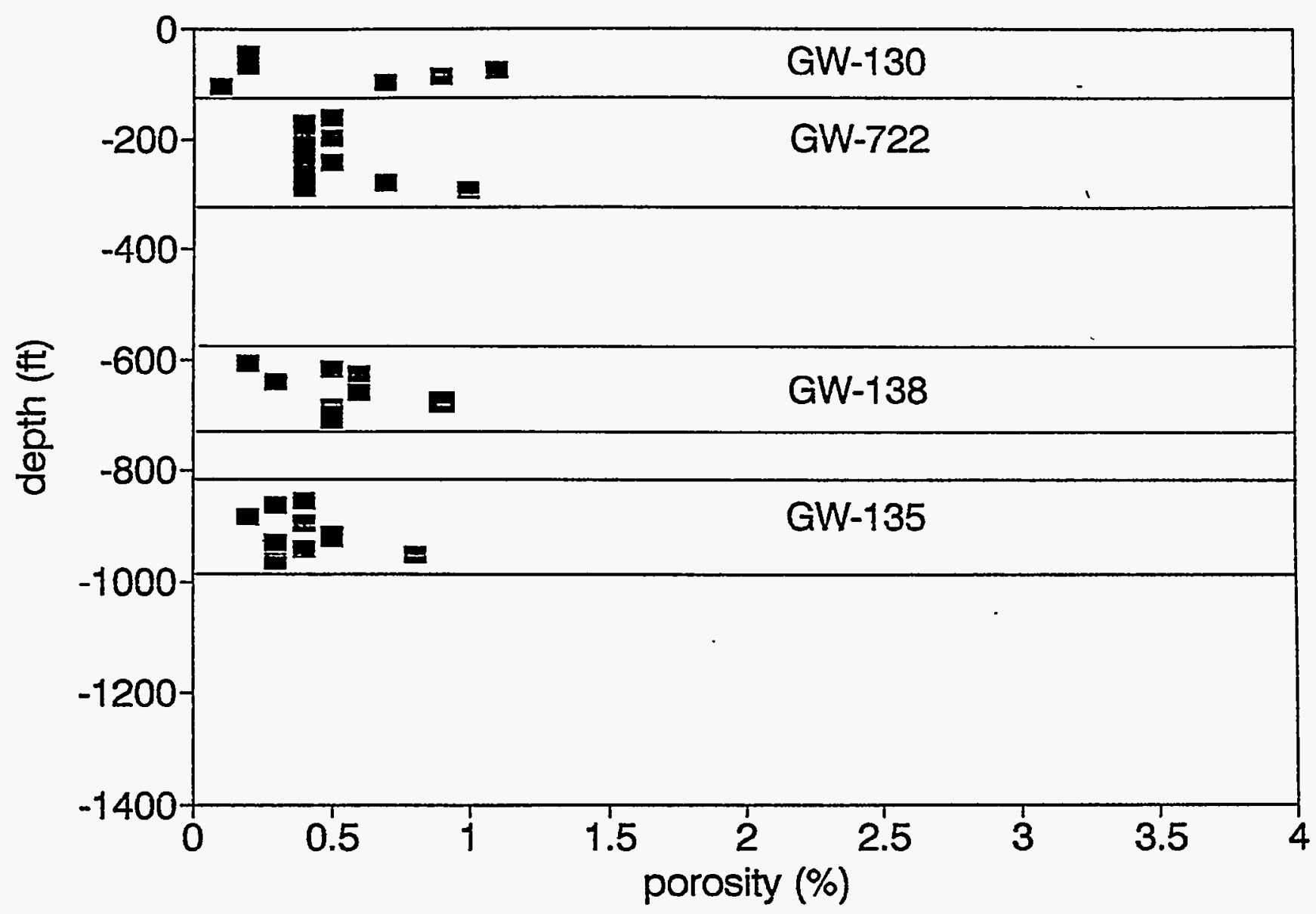

Fig. 3.8: Matrix porosities with respect to depth in Zone 4 of the Maynardville Limestone. 


\section{ZONE 3}

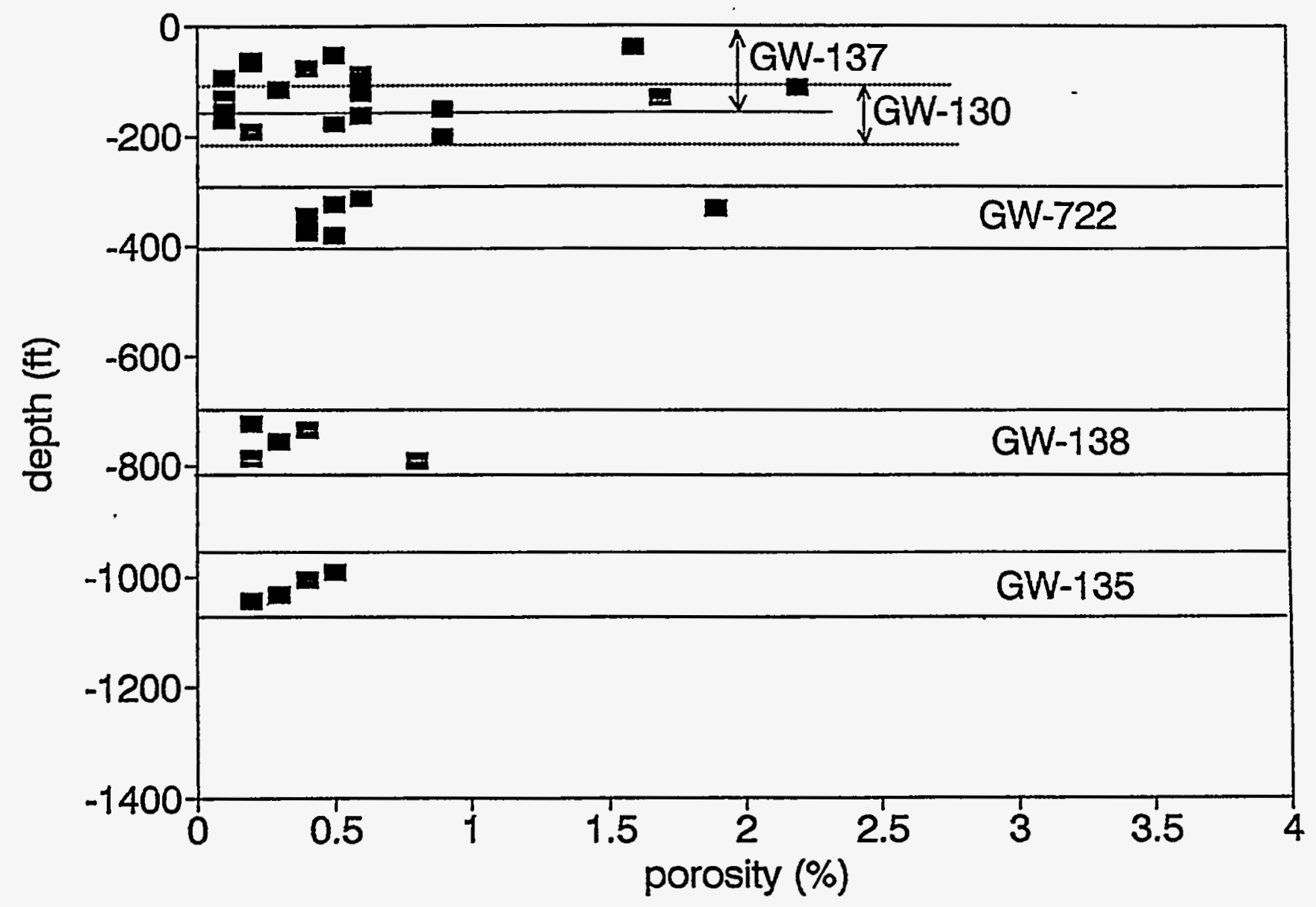

Fig. 3.9: Matrix porosities with respect to depth in Zone 3 of the Maynardville Limestone. 
ZONE 2

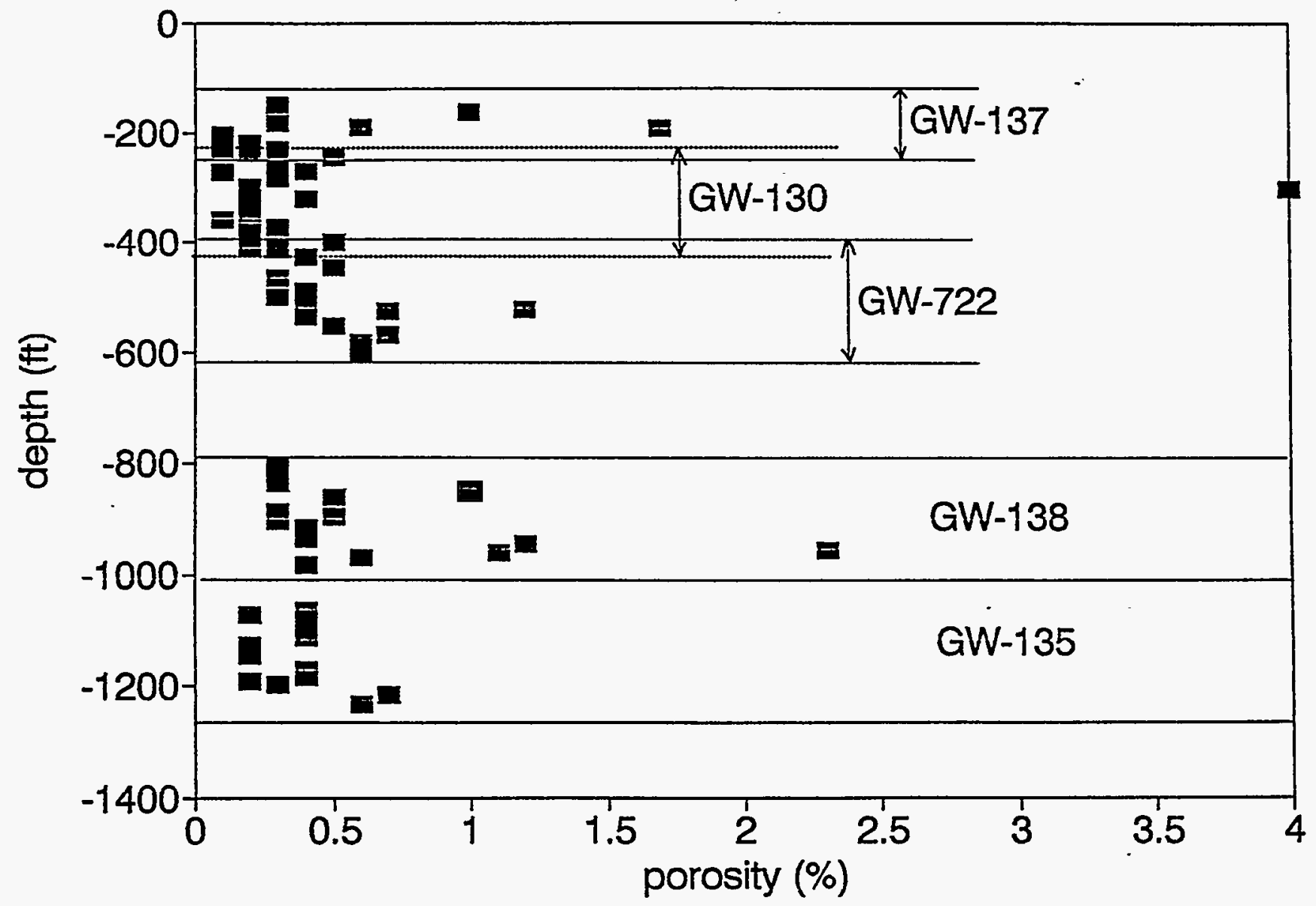

Fig. 3.10: Matrix porosities with respect to depth in Zone 2 of the Maynardville Limestone. 
GW-135 AND GW-138

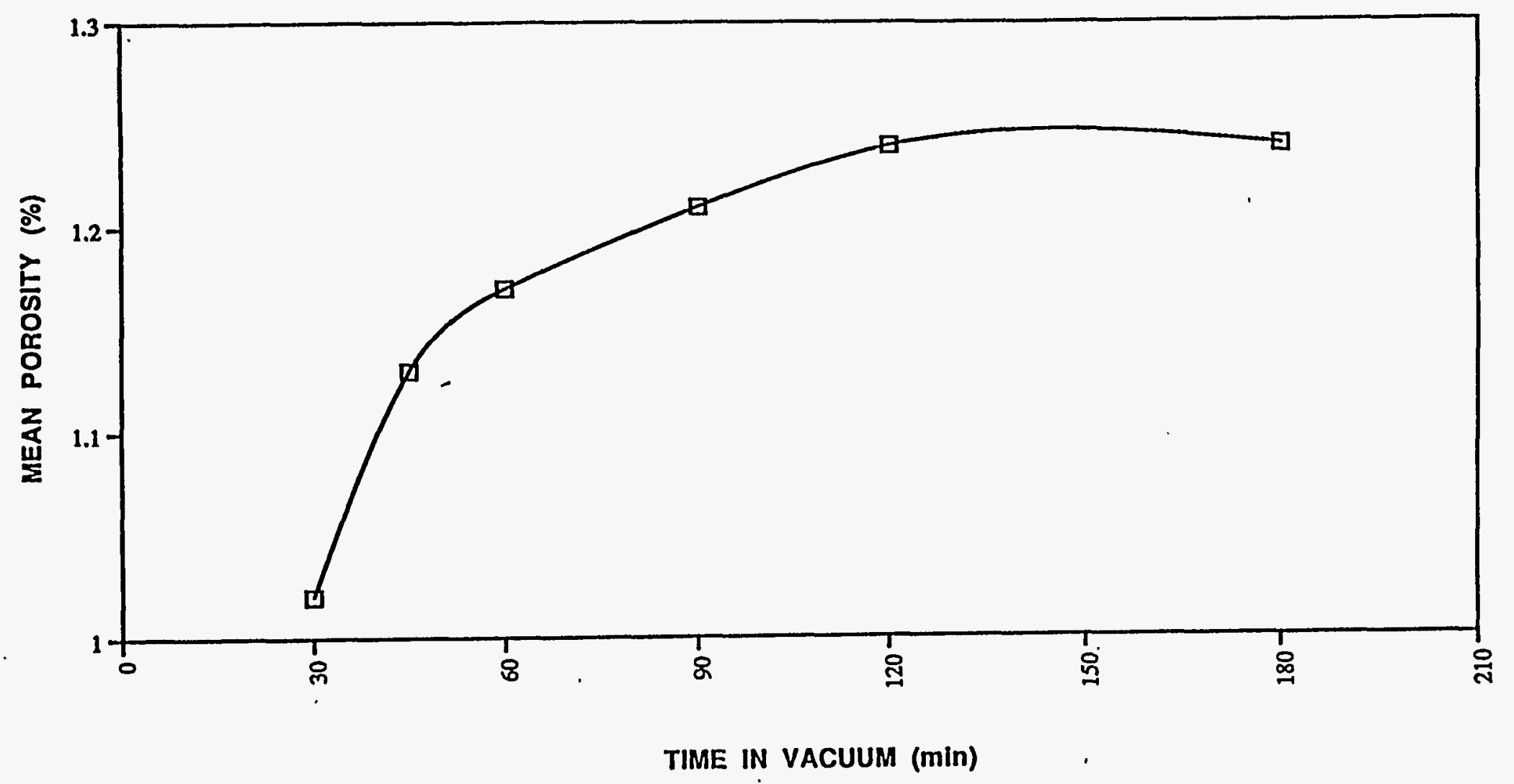

Fig. 5.1: Mean porosities of carbonate rock samples from GW-135 and GW-138 at varying time intervals in a vacuum. 
Table 1.1: Porosity data from the JOY-1 core (from de Laguna and others 1969).

Depth (ft)

155

508

660

719

801

\begin{tabular}{lll} 
& Depth (ft) & Porosity (\%) \\
Conasauga & 155 & 1.3 \\
Shale & 508 & 1.1 \\
& 660 & 0.46 \\
& 719 & 1.1 \\
& 801 & 1.9 \\
\hline Chickamauga & 2086 & \\
Limestone & 2701 & 0.49 \\
& 2705 & 0.39 \\
& 2826 & 0.54 \\
& 2852 & 1.5 \\
& & 0.78
\end{tabular}

Porosity (\%)

1.3 
Table 3.1: Mean matrix porosities for the Maynardville Limestone and Copper Ridge Dolomite.

\begin{tabular}{llll} 
Formation/ & Standard & Number of \\
Zone & Mean & Deviation & Samples \\
\hline
\end{tabular}

Maynardville Limestone

\begin{tabular}{|c|c|c|c|}
\hline Zone 6 & $2.1 \%$ & 2.0 & 66 \\
\hline Zone 5 & $0.8 \%$ & 0.6 & 42 \\
\hline Zone 4 & $0.5 \%$ & 0.2 & 105 \\
\hline Zone 3 & $0.6 \%$ & 0.5 & 75 \\
\hline Zone 2 & $0.5 \%$ & 0.5 & 219 \\
\hline Total & $0.8 \%$ & 0.4 & \\
\hline
\end{tabular}

Copper Ridge Dolomite

$1.3 \% \quad 0.5 \quad 294$




\section{APPENDIX A: VOLUMETRIC POROSITY DATA}

WELL DEPTH ZONE VOLUMETRIC POROSITY

\begin{tabular}{|c|c|c|c|c|c|c|c|}
\hline & 3GS) & & (\%) & $(\%)$ & $(\%)$ & volumetric & \\
\hline & & & test 1 & test 2 & test 3 & mean & std \\
\hline GW-130 & -44.5 & 4 & 0.1 & 0.1 & 0.3 & 0.2 & 0.1 \\
\hline & -67 & 4 & 0.2 & 0.1 & 0.2 & 0.2 & 0.0 \\
\hline & -73.5 & 4 & 1 & 1.2 & 1.2 & 1.1 & 0.1 \\
\hline & -86 & 4 & 1.5 & 0.3 & 1 & 0.9 & 0.5 \\
\hline & -97 & 4 & 1.1 & 0.9 & 0.2 & 0.7 & 0.4 \\
\hline & -106 & 4 & 0.2 & 0.1 & 0.1 & 0.1 & 0.0 \\
\hline & -117 & 3 & 0.2 & 0.4 & 0.3 & 0.3 & 0.1 \\
\hline & -125 & 3 & 1 & 0.3 & 0.5 & 0.6 & 0.3 \\
\hline & -132 & 3 & 0.1 & 0.2 & 0.1 & 0.1 & 0.0 \\
\hline & -144 & 3 & 0 & 0.1 & 0.3 & 0.1 & 0.1 \\
\hline & -151 & 3 & 0.9 & 0.6 & 1.1 & 0.9 & 0.2 \\
\hline & -162 & 3 & 0.6 & 0.8 & 0.4 & 0.6 & 0.2 \\
\hline & -171 & 3 & 0.1 & 0.1 & 0.1 & 0.1 & 0.0 \\
\hline & -178 & 3 & 0.4 & 0.8 & 0.2 & 0.5 & 0.2 \\
\hline & -191.5 & 3 & 0.2 & 0.3 & 0.1 & 0.2 & 0.1 \\
\hline & -200 & 3 & 0.8 & 1.1 & 0.7 & 0.9 & 0.2 \\
\hline & -204 & 2 & 0.1 & 0.2 & 0.1 & 0.1 & 0.0 \\
\hline & -215.5 & 2 & 0.2 & 0.1 & 0.1 & 0.1 & 0.0 \\
\hline & -230 & 2 & 0.2 & 0.1 & 0.1 & 0.1 & 0.0 \\
\hline & -244 & 2 & 0.5 & 0.5 & 0.4 & 0.5 & 0.0 \\
\hline & -254.5 & 2 & 0.3 & 0.3 & 0.3 & 0.3 & 0.0 \\
\hline & -269.5 & 2 & 0.3 & 0.4 & 0.5 & 0.4 & 0.1 \\
\hline & -272.5 & 2 & 0.1 & 0.1 & 0.1 & 0.1 & 0.0 \\
\hline & -281 & 2 & 0.1 & 0.4 & 0.3 & 0.3 & 0.1 \\
\hline & -299 & 2 & 0.2 & 0.2 & 0.1 & 0.2 & 0.0 \\
\hline & -302 & 2 & 4.2 & 4.1 & 3.7 & 4.0 & 0.2 \\
\hline & -311 & 2 & 0.2 & 0.2 & 0.1 & 0.2 & 0.0 \\
\hline & -321 & 2 & 0.5 & 0.3 & 0.3 & 0.4 & 0.1 \\
\hline & -333 & 2 & 0.1 & 0.2 & 0.2 & 0.2 & 0.0 \\
\hline & -337 & 2 & 0.2 & 0.2 & 0.1 & 0.2 & 0.0 \\
\hline & -348 & 2 & 0.2 & 0.2 & 0.2 & 0.2 & 0.0 \\
\hline & -358.5 & 2 & 0.1 & 0.1 & 0.2 & 0.1 & 0.0 \\
\hline & -372.5 & 2 & 0.3 & 0.3 & 0.2 & 0.3 & 0.0 \\
\hline & -380 & 2 & 0.2 & 0.2 & 0.1 & 0.2 & 0.0 \\
\hline & -391 & 2 & 0.2 & 0.2 & 0.1 & 0.2 & 0.0 \\
\hline & -394.5 & 2 & 0.1 & 0.3 & 0.3 & 0.2 & 0.1 \\
\hline & -406 & 2 & 0.5 & 0.2 & 0.3 & 0.3 & 0.1 \\
\hline & -411 & 2 & 0.1 & 0.3 & 0.2 & 0.2 & 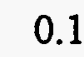 \\
\hline
\end{tabular}


WELL DEPTH ZONE POROSITY VOLUMEIRIC POROSITY (BGS)

\begin{tabular}{|c|c|c|c|c|c|c|c|c|}
\hline & \multicolumn{2}{|r|}{ petrographic } & & & & mean & \\
\hline \multirow{2}{*}{ GW-135 } & -634.5 & $\mathrm{Cer}$ & & 1 & 1 & 0.9 & 1.0 & 0.0 \\
\hline & -638 & $\mathrm{Cct}$ & & 0.7 & 0.8 & 0.8 & 0.8 & 0.0 \\
\hline & -665 & $\mathrm{Crt}$ & & 1.6 & 0.8 & 1.5 & 1.3 & 0.4 \\
\hline & -697.5 & 6 & & 0.2 & 0.3 & 0.5 & 0.3 & 0.1 \\
\hline & -714 & 6 & & 1.7 & 1.6 & 1.7 & 1.7 & 0.0 \\
\hline & .731 .5 & 6 & 1.6 & 2.4 & 1 & 0.9 & 1.4 & 0.7 \\
\hline & .745 & 6 & 1.3 & 2.4 & 2.7 & 1.9 & 2.3 & 0.3 \\
\hline & -755 & 6 & & 0.2 & 0.6 & 0.4 & 0.4 & 0.2 \\
\hline & -769 & 6 & 10.3 & 1.7 & 2.6 & 0.9 & 1.7 & 0.7 \\
\hline & .775 & 6 & & 0.4 & 0.2 & 0.3 & 0.3 & 0.1 \\
\hline & -785 & 6 & & 0.6 & 0.2 & 1.4 & 0.7 & 0.5 \\
\hline & -795 & 6 & & 0.4 & 0.9 & 0.4 & 0.6 & 0.2 \\
\hline & -798 & 6 & & 1.1 & 0.7 & 1.7 & 1.2 & 0.4 \\
\hline & -808 & 5 & 0.3 & 0.6 & 0.8 & 0.8 & 0.7 & 0.1 \\
\hline & 817.5 & 5 & 0 & 0.5 & 0.2 & 0.5 & 0.4 & 0.1 \\
\hline & -825 & 5 & & 0.4 & 0.3 & 0.5 & 0.4 & 0.1 \\
\hline & -837.5 & 5 & 0 & 1.3 & 2 & 3.7 & 2.3 & 1.0 \\
\hline & 845 & 5 & & 0.4 & 0.7 & 0.6 & 0.6 & 0.1 \\
\hline & -855 & 4 & & 0.3 & 0.3 & 0.5 & 0.4 & 0.1 \\
\hline & -863 & 4 & & 0.3 & 0.2 & 0.4 & 0.3 & 0.1 \\
\hline & -882.5 & 4 & 0 & 0.2 & 0.2 & & 0.2 & 0.0 \\
\hline & -895 & 4 & & 0.4 & 0.5 & 0.2 & 0.4 & 0.1 \\
\hline & -913 & 4 & & 0.5 & 0.5 & 0.5 & 0.5 & 0.0 \\
\hline & -921 & 4 & & 0.3 & 0.6 & 0.6 & 0.5 & 0.1 \\
\hline & -930 & 4 & & 0.4 & 0.4 & 0.2 & 0.3 & 0.1 \\
\hline & -940 & 4 & & 0.2 & 0.2 & 0.7 & 0.4 & 0.2 \\
\hline & -953 & 4 & 0 & 1.3 & 0.8 & 0.4 & 0.8 & 0.4 \\
\hline & -963 & 4 & & 0.2 & 0.4 & 0.3 & 0.3 & 0.1 \\
\hline & -991.5 & 3 & & 0.4 & 0.7 & 0.4 & 0.5 & 0.1 \\
\hline & -1006 & 3 & 0 & 0.5 & 0.6 & 0.2 & 0.4 & 0.2 \\
\hline & -1033 & 3 & & 0.4 & 0.4 & 0.2 & 0.3 & 0.1 \\
\hline & -1044 & 3 & 0 & 0.2 & 0.3 & 0.2 & 0.2 & 0.0 \\
\hline & -1063 & 2 & & 0.5 & 0.2 & 0.5 & 0.4 & 0.1 \\
\hline & -1073 & 2 & & 0.2 & 0.2 & 0.2 & 0.2 & 0.0 \\
\hline & -1092 & 2 & & 0.3 & 0.6 & 0.3 & 0.4 & 0.1 \\
\hline & -1112 & 2 & & 0.4 & 0.2 & 0.6 & 0.4 & 0.2 \\
\hline & -1127.5 & 2 & & 0.2 & 0.2 & 0.3 & 0.2 & 0.0 \\
\hline & -1133 & -2 & 0 & 0.2 & 0.2 & 0.2 & 0.2 & 0.0 \\
\hline & -1146 & 2 & & 0.3 & 0.2 & 0.2 & 0.2 & 0.0 \\
\hline & -1170 & 2 & & 0.4 & 0.4 & 0.4 & 0.4 & 0.0 \\
\hline & -1183 & 2 & & 0.6 & 0.4 & 0.2 & 0.4 & 0.2 \\
\hline & -1192 & 2 & & 0.3 & 0.2 & 0.2 & 0.2 & 0.0 \\
\hline & -1198 & 2 & 0.3 & 0.2 & 0.6 & 0.2 & 0.3 & 0.2 \\
\hline & -1215 & 2 & & 0.8 & 0.8 & 0.6 & 0.7 & 0.1 \\
\hline & & 2 & & 0.2 & 0.4 & 1.2 & 0.6 & 0.4 \\
\hline
\end{tabular}




\begin{tabular}{|c|c|c|c|c|c|c|c|c|}
\hline WELI & $\begin{array}{l}\text { DEPTH } \\
\text { (BGS) }\end{array}$ & ZONE & $\begin{array}{r}\text { POROSITY } \\
(\%) \\
\text { petrographic }\end{array}$ & $\begin{array}{c}\text { VOLUMETRIC P } \\
(\%) \\
\text { test } 1\end{array}$ & $\begin{array}{c}\text { ROSITY } \\
(\%) \\
\text { test } 2\end{array}$ & $\begin{array}{r}(\%) \\
\text { test } 3\end{array}$ & $\begin{array}{r}\text { volumetric } \\
\text { mean }\end{array}$ & std \\
\hline \multirow[t]{18}{*}{ GW-137 } & -39 & 3 & & 2.1 & 0.8 & 1.8 & 1.6 & 0.6 \\
\hline & -53 & 3 & & 0.4 & 0.6 & 0.5 & 0.5 & 0.1 \\
\hline & -65 & 3 & & 0.2 & 0.2 & 0.3 & 0.2 & 0.0 \\
\hline & -78 & 3 & & 0.7 & 0.1 & 0.3 & 0.4 & 0.2 \\
\hline & -88 & 3 & & 0.4 & 0.5 & 1 & 0.6 & 0.3 \\
\hline & -95 & 3 & & 0.2 & 0.1 & 0.1 & 0.1 & 0.0 \\
\hline & -112 & 3 & & 1 & 2.7 & 3 & 2.2 & 0.9 \\
\hline & -119 & 3 & & 0.9 & 0.5 & 0.3 & 0.6 & 0.2 \\
\hline & -131.5 & 3 & 0 & 2.5 & 5 & 0.6 & 2.7 & 1.8 \\
\hline & -148 & 2 & & 0.2 & 0.4 & 0.2 & 0.3 & 0.1 \\
\hline & -162.5 & 2 & & 2.7 & 0.1 & 0.1 & 1.0 & 1.2 \\
\hline & -180 & 2 & & 0.2 & 0.5 & 0.1 & 0.3 & 0.2 \\
\hline & -189 & 2 & & 0.6 & 0.3 & 0.8 & 0.6 & 0.2 \\
\hline & -193 & 2 & & 0.8 & 2.4 & 2 & 1.7 & 0.7 \\
\hline & -206 & 2 & & 0 & 0.2 & 0.2 & 0.1 & 0.1 \\
\hline & -218.5 & 2 & 3 & 0.3 & 0.2 & 0.1 & $0.2^{-}$ & 0.1 \\
\hline & -229 & 2 & & 0.3 & 0.2 & 0.5 & 0.3 & 0.1 \\
\hline & -236 & 2 & & 0.2 & 0.3 & 0.1 & 0.2 & 0.1 \\
\hline
\end{tabular}


WELI DEPTH ZONE POROSITY VOLUMETRICPOROSITY

(BGS)

GW-138
(\%)

petrographic

$\begin{array}{rrr}-432.5 & \mathrm{Ccr} & 15 \\ -450 & 6 & \end{array}$

$-462$

$-475 \quad 6$

$-483$

$-488$

$-505$

$-522$

$-526$

.539

.560

$-567$

$-575$

$-593$

$-605$

$-617.5$

$-626$

$-639$

$-658$

$-678$

$-685$

$-708.5$

$-722$

$-735$

$-755$

$-785$

$-792.5$

$-805$

$-835$

$-849$

$-860$

$-885.5$

$-895$

$-903$

.915

$-935$

$-945$

$-954.5$

$-960$

.967

$-981$

$\begin{array}{rr}\mathrm{Car} & \text { Petrographic } \\ \mathrm{Cor} & \\ \mathrm{Cor} & \\ 6 & \\ 6 & \\ 6 & \end{array}$

4.3

0

0

0

0

0

3

1.3
(\%)

test 1

0.5

1.3

5.1

2.2

3.4

7.8

3.8

6.3

5.7

2.5

0.5

0.4

0.3

0.5

0.2

0.5

0.2

0.8

0.6

0.3

0.4

0.9

0.7

0.5

0.2

0.6

0.2

0.3

1

0.3

0.2

1.8

0.5

0.4

0.8

0.4

0.2

0.3

1.9

4.3

0.4

0.4

0.4
(\%)

test 2

test 3

$2.8 \quad 0.6$

$1.1 \quad 1.5$

$8.4 \quad 5.1$

20.9

$5.5 \quad 5.3$

$1.1 \quad 1.6$

$3.1 \quad 5.9$

$6.1 \quad 7.2$

$10.8 \quad 5.2$

$4.3 \quad 7.8$

1.10 .2

$0.5 \quad 0.5$

$0.4 \quad 0.4$

$0.5 \quad 0.4$

$0.4 \quad 0.2$

$0.4 \quad 0.5$

$0.2 \quad 0.2$

$0.4 \quad 0.3$

$0.7 \quad 0.4$

$0.3 \quad 0.3$

10.4

$0.4 \quad 0.5$

$0.4 \quad 0.5$

$0.3 \quad 0.2$

$0.2 \quad 0.4$

$0.2 \quad 0.5$

$0.2 \quad 0.2$

$0.3 \quad 1.1$

$0.4 \quad 0.3$

$0.4 \quad 0.3$

$0.6 \quad 0.6$

$0.5 \quad 0.5$

$0.3 \quad 0.3$

$0.2 \quad 0.5$

$0.2 \quad 0.2$

$\begin{array}{ll}0.4 & 0.5\end{array}$

$0.6 \quad 0.4$

$0.7 \quad 0.9$

$1.3 \quad 3.4$

$1.5 \quad 1.4$

$0.4 \quad 0.9$

$0.4 \quad 0.4$ volumetric

mean std

$1.3 \quad 1.1$

$1.3 \quad 0.2$

$6.2 \quad 1.6$

$1.7 \quad 0.6$

$\begin{array}{ll}4.7 & 0.9\end{array}$

$3.5 \quad 3.0$

$4.3 \quad 1.2$

$\begin{array}{ll}6.5 & 0.5\end{array}$

$7.2 \quad 2.5$

$4.9 \quad 2.2$

$0.6 \quad 0.4$

$\begin{array}{ll}0.5 & 0.0\end{array}$

$0.4 \quad 0.0$

$0.5 \quad 0.0$

$0.3 \quad 0.1$

$0.5 \quad 0.0$

$0.2 \quad 0.0$

$\begin{array}{ll}0.5 & 0.2\end{array}$

$0.6 \quad 0.1$

$0.3 \quad 0.0$

$0.6 \quad 0.3$

$0.9 \quad 0.0$

$0.5 \quad 0.1$

$0.5 \quad 0.0$

$0.2 \quad 0.0$

$0.4 \quad 0.2$

$0.3 \quad 0.1$

$0.2 \quad 0.0$

$0.8 \quad 0.4$

$0.3 \quad 0.0$

$0.3 \quad 0.1$

$1.0 \quad 0.6$

$0.5 \quad 0.0$

$0.3 \quad 0.0$

$0.5 \quad 0.2$

$0.3 \quad 0.1$

$0.4 \quad 0.1$

$0.4 \quad 0.1$

$1.2 \quad 0.5$

$2.3 \cdot 1.4$

$1.1 \quad 0.5$

$\begin{array}{ll}0.6 & 0.2\end{array}$

$\begin{array}{lll}0.4 & 0.0\end{array}$ 
WELI DEPTT
(BGS)

GW-722

ZONE POROSTTY VOLUMETRIC POROSTTY

(\%)

petrographic

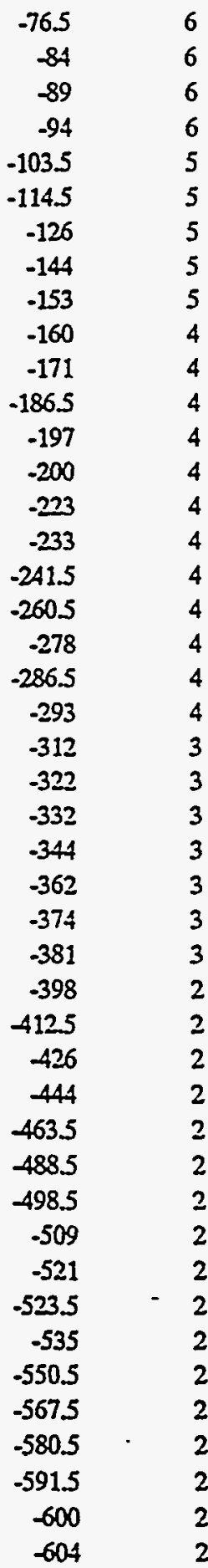

(\%)

test 1

1.4

1.4

0.9

0.6

0.5

1.5

0.9

1.2

0.4

0.6

0.2

0.5

0.4

0.2

0.4

0.4

0.4

0.4

0.7

0.3

0.7

0.9

0.8

3.6

0.4

0.3

0.4

0.5

0.4

0.3

0.3

0.4

0.3

0.4

0.3

0.4

0.6

0.7

0.4

0.5

0.5

0.6

0.7

0.5

0.2
(\%) test 2

1

1.5

0.8

0.6

1.4

1.7

2.7

0.4

0.2

0.2

0.7

0.9

0.7

0.5

0.4

0.3

0.4

0.3

0.7

0.2

1.7

0.6

0.4

0.6

0.2 .

0.4

0.4

0.4

0.4

0.4

0.4

0.5

0.4

0.3

0.2

0.4

1.5

0.5

0.4

0.5

1

0.6

0.6

0.4

0.6
(\%) volumetric

test 3

0.9

2.4

1.4

1.9

3.1

1.1

0.9

0.6

0.2

0.6

0.4

0.3

0.5

0.4

0.4

0.5

0.6

0.4

0.7

0.6

0.6

0.4

0.3

1.6

0.6

0.6

0.4

0.5

0.7

0.2

0.6

0.7

0.3

0.6

0.3

0.3

1.5

0.8

0.4

0.6

0.7

0.7

0.6

0.9

0.5 mean sic

$1.1 \quad 0.2$

$1.8 \quad 0.4$

$1.0 \quad 0.3$

$1.0 \quad 0.6$

$1.7 \quad 1.1$

$1.4 \quad 0.2$

1.50 .8

$0.7 \quad 0.3$

$0.3 \quad 0.1$

$0.5 \quad 0.2$

$0.4 \quad 0.2$

$0.4 \quad 0.2$

$0.5 \quad 0.1$

$0.4 \quad 0.1$

$0.4 \quad 0.0$

$0.4^{-} \quad 0.1$

$0.5 \quad 0.1$

$0.4 \quad 0.0$

$0.7 \quad 0.0$

$0.4 \quad 0.2$

$1.0 \quad 0.5$

$0.6 \quad 0.2$

$0.5 \quad 0.2$

$1.9 \quad 1.2$

$0.4 \quad 0.2$

$0.4 \quad 0.1$

$0.4 \quad 0.0$

$0.5 \quad 0.0$

$0.5 \quad 0.1$

$\begin{array}{ll}0.3 & 0.1\end{array}$

$0.4 \quad 0.1$

$0.5 \quad 0.1$

$0.3 \quad 0.0$

$0.4 \quad 0.1$

$0.3 \quad 0.0$

$0.4 \quad 0.0$

$1.2 \quad 0.4$

$0.7 \quad 0.1$

$\begin{array}{ll}0.4 & 0.0\end{array}$

$0.5 \quad 0.0$

$\begin{array}{ll}0.7 & 0.2\end{array}$

$0.6 \quad 0.0$

$\begin{array}{ll}0.6 & 0.0\end{array}$

$0.6 \quad 0.2$

$0.4 \quad 0.2$ 
Copper Ridge Dolomite

WELL DEPTH VOLUMETRIC POROSITY

\begin{tabular}{|c|c|c|c|c|c|c|}
\hline & (BGS) & $(\%)$ & $(\%)$ & $(\%)$ & volumetric & std \\
\hline GW-135 & -68 & $\begin{array}{r}\text { test } 1 \\
3.6\end{array}$ & $\begin{array}{r}\text { test } 2 \\
2.8\end{array}$ & $\begin{array}{r}\text { test } 3 \\
3.4\end{array}$ & $\begin{array}{r}\text { mean } \\
3.3\end{array}$ & 0.4 \\
\hline & -83.5 & 0.8 & 0.7 & 7.2 & 2.9 & 3.7 \\
\hline & -96 & 0.2 & 0.2 & 0.4 & 0.3 & 0.1 \\
\hline & -105.5 & 0.9 & 0.2 & 0.2 & 0.4 & 0.4 \\
\hline & -112 & 1.2 & 1.4 & 1.4 & 1.3 & 0.1 \\
\hline & -124 & 3.5 & 0.1 & 1.8 & 1.8 & 1.7 \\
\hline & -133 & 0.8 & 1.0 & 1.2 & 1.0 & 0.2 \\
\hline ' & -140.5 & 0.3 & 0.3 & 0.7 & 0.4 & 0.2 \\
\hline & -149.5 & 0.7 & 0.4 & 0.3 & 0.4 & 0.2 \\
\hline & -159.5 & 0.6 & 1.0 & 0.2 & 0.6 & 0.4 \\
\hline & -164 & 0.4 & 0.6 & 0.9 & 0.6 & 0.2 \\
\hline & .180 & 1.8 & 0.8 & 0.6 & 1.0 & 0.6 \\
\hline & .185 & 2.0 & 0.8 & 0.6 & 1.1 & 0.8 \\
\hline & -199 & 1.5 & 0.8 & 0.6 & 1.0 & 0.5 \\
\hline & -205 & 1.7 & 1.5 & 1.0 & 1.4 & 0.4 \\
\hline & -211.5 & 0.8 & 0.9 & 1.0 & 0.9 & 0.1 \\
\hline & -220 & 2.3 & 0.5 & 0.5 & 1.1 & 1.0 \\
\hline & -230 & 0.7 & 0.6 & 0.9 & 0.7 & 0.1 \\
\hline & -236 & 0.6 & 0.6 & 0.6 & 0.6 & 0.0 \\
\hline & -252 & 0.2 & 0.4 & 0.2 & 0.2 & 0.1 \\
\hline & -255 & 0.4 & 0.2 & 0.3 & 0.3 & 0.1 \\
\hline & -265 & 0.5 & 0.4 & 0.8 & 0.5 & 0.2 \\
\hline & -280 & 0.6 & 0.4 & 0.6 & 0.6 & 0.1 \\
\hline & -287 & 0.4 & 0.4 & 0.4 & 0.4 & 0.0 \\
\hline & -299.5 & 1.1 & 0.6 & 0.5 & 0.7 & 0.3 \\
\hline & -305.5 & 0.5 & 0.5 & 0.8 & 0.6 & 0.2 \\
\hline & .312 & 0.8 & 0.9 & 1.1 & 0.9 & 0.1 \\
\hline & -322.5 & 0.6 & 0.6 & 1.0 & 0.8 & 0.2 \\
\hline & .332 & 1.3 & 6.6 & 0.7 & 2.9 & 3.3 \\
\hline & .343 & 1.5 & 1.4 & 1.3 & 1.4 & 0.1 \\
\hline & -353 & 0.6 & 0.5 & 0.4 & 0.5 & 0.1 \\
\hline & -361 & 0.8 & 0.5 & 1.0 & 0.8 & 0.2 \\
\hline & -371.5 & 0.1 & 0.2 & 0.2 & 0.2 & 0.1 \\
\hline & .384 & 3.8 & 4.2 & 4.0 & 4.0 & 0.2 \\
\hline & .390 & 11.0 & 2.7 & 9.7 & 7.8 & 4.5 \\
\hline & -399 & 2.5 & 0.8 & 0.9 & 1.4 & 0.9 \\
\hline & -406.5 & 1.3 & .0 .4 & 0.4 & 0.7 & 0.5 \\
\hline & -413.5 & 11.3 & 7.5 & 5.4 & 8.1 & 3.0 \\
\hline & -427.5 & 0.4 & 3.0 & 2.3 & 1.9 & 1.3 \\
\hline & -433 & 2.6 & 0.8 & 1.8 & 1.7 & 0.9 \\
\hline & -448 & 1.0 & 0.3 & 0.4 & 0.6 & 0.4 \\
\hline & -452.5 & 7.4 & 5.0 & 5.8 & 6.1 & 1.2 \\
\hline & -465 & 3.7 & 2.3 & 3.2 & 3.1 & 0.7 \\
\hline & .474 & 1.4 & 0.9 & 0.6 & 1.0 & 0.4 \\
\hline
\end{tabular}




\begin{tabular}{|c|c|c|c|c|c|c|}
\hline \multirow[t]{3}{*}{ WELL } & \multirow{3}{*}{$\begin{array}{l}\text { DEPTH } \\
\text { (BGS) }\end{array}$} & \multicolumn{5}{|c|}{ VOLUMETRIC POROSITY } \\
\hline & & $(\%)$ & $(\%)$ & $(\%)$ & volumetric & \\
\hline & & test 1 & test 2 & test 3 & mean & std \\
\hline \multirow[t]{16}{*}{ GW-135 } & -485 & 0.2 & 0.4 & 0.5 & 0.4 & 0.1 \\
\hline & -494.5 & 0.5 & 0.2 & 0.3 & 0.3 & 0.1 \\
\hline & .503 .5 & 0.2 & 0.1 & 0.2 & 0.1 & 0.1 \\
\hline & -507.5 & 0.6 & 0.4 & 0.6 & 0.5 & 0.1 \\
\hline & -522.5 & 0.7 & 0.6 & 3.8 & 1.7 & 1.8 \\
\hline & -525 & 0.9 & 0.4 & 0.5 & 0.6 & 0.3 \\
\hline & -535 & & 0.6 & 0.9 & 0.7 & 0.3 \\
\hline & -550.5 & 0.3 & 0.5 & 2.5 & 1.1 & 1.2 \\
\hline & -561.5 & 0.7 & 0.5 & 0.4 & 0.6 & 0.1 \\
\hline & -569.5 & 1.4 & 1.1 & 0.5 & 1.0 & 0.4 \\
\hline & -571.5 & 1.6 & 0.4 & 1.4 & 1.1 & 0.6 \\
\hline & -585 & 0.7 & 0.8 & 0.8 & 0.8 & 0.1 \\
\hline & .594 & 1.4 & 0.9 & 5.0 & 2.5 & 2.3 \\
\hline & -605 & 0.3 & 0.5 & 0.2 & 0.3 & 0.1 \\
\hline & -611 & 0.5 & 0.5 & 0.4 & 0.5 & 0.0 \\
\hline & -627 & 0.1 & 0.7 & 0.2 & 0.3 & 0.3 \\
\hline \multirow[t]{28}{*}{$G W-138$} & -41 & 0.7 & 0.8 & 0.7 & 0.7 & 0.1 \\
\hline & -52.5 & 0.7 & 0.3 & 0.8 & 0.6 & 0.2 \\
\hline & -58.5 & 0.4 & 0.7 & 0.7 & 0.6 & 0.1 \\
\hline & .66 & 0.5 & 2.2 & 2.1 & 1.6 & 1.0 \\
\hline & -75.5 & 0.5 & 0.5 & 1.1 & 0.7 & 0.3 \\
\hline & -89.5 & 1.3 & 1.2 & 1.5 & 1.3 & 0.1 \\
\hline & -95 & 0.6 & 1.1 & 1.5 & 1.0 & 0.5 \\
\hline & -105 & 1.6 & 1.2 & 0.8 & 1.2 & 0.4 \\
\hline & -111 & 0.7 & 0.8 & 0.6 & 0.7 & 0.1 \\
\hline & -128 & 1.1 & 0.9 & 1.1 & 1.0 & 0.1 \\
\hline & -135 & 0.6 & 0.8 & 0.8 & 0.7 & 0.1 \\
\hline & -145.5 & 0.4 & 0.6 & 0.6 & 0.5 & 0.1 \\
\hline & -152.5 & 4.7 & 2.9 & 3.0 & 3.5 & 1.0 \\
\hline & -159.5 & 0.8 & 0.8 & 0.6 & 0.8 & 0.1 \\
\hline & -170.5 & 1.0 & 0.4 & 0.6 & 0.6 & 0.3 \\
\hline & -177.5 & 3.1 & 5.4 & 8.5 & 5.6 & 2.7 \\
\hline & -191 & 0.8 & 0.6 & 0.8 & 0.7 & 0.1 \\
\hline & -201.5 & 0.8 & 0.8 & 0.4 & 0.7 & 0.2 \\
\hline & -205 & 0.7 & 0.4 & 0.3 & 0.5 & .0 .2 \\
\hline & -215 & 1.1 & 0.4 & 0.6 & 0.7 & 0.4 \\
\hline & -225 & 0.5 & 0.4 & 0.4 & 0.4 & 0.1 \\
\hline & -232.5 & 0.6 & 0.4 & 0.6 & 0.5 & 0.1 \\
\hline & -247 & 0.4 & 0.1 & 0.3 & 0.3 & 0.1 \\
\hline & -249 & 0.3 & 0.7 & 0.7 & 0.5 & 0.2 \\
\hline & -261 & 0.5 & 0.6 & 0.6 & 0.6 & 0.1 \\
\hline & -271.5 & 0.6 & 0.7 & 1.1 & 0.8 & 0.2 \\
\hline & -283.5 & 0.3 & 0.5 & 0.9 & 0.6 & 0.3 \\
\hline & -294 & 0.8 & 0.6 & 0.5 & 0.6 & 0.1 \\
\hline
\end{tabular}


Copper Ridge Dolomite

\begin{tabular}{|c|c|c|c|c|c|c|}
\hline \multirow[t]{3}{*}{ WELL } & \multirow{3}{*}{$\begin{array}{l}\text { DEPTH } \\
\text { (BGS) }\end{array}$} & \multicolumn{5}{|c|}{ VOLUMETRIC POROSITY } \\
\hline & & $(\%)$ & $(\%)$ & $(\%)$ & volumetric & \\
\hline & & test 1 & test 2 & test 3 & mean & std \\
\hline \multirow[t]{8}{*}{ GW-138 } & -306 & 1.3 & 0.9 & 1.6 & 1.2 & 0.3 \\
\hline & -310 & 0.5 & 1.5 & 1.1 & 1.1 & 0.5 \\
\hline & .322 .5 & 0.5 & 0.5 & 0.9 & 0.6 & 0.2 \\
\hline & -328.5 & 0.4 & 0.4 & 0.5 & 0.4 & 0.1 \\
\hline & -342.5 & 1.0 & 0.7 & & 0.9 & 0.2 \\
\hline & -347 & 1.5 & 0.6 & 0.9 & 1.0 & 0.5 \\
\hline & -361.5 & 5.7 & 4.8 & 6.6 & 5.7 & 0.9 \\
\hline & -372 & 1.5 & 0.6 & 1.3 & 1.1 & 0.4 \\
\hline \multirow[t]{3}{*}{. } & -374.5 & 1.1 & 0.9 & & 1.0 & 0.1 \\
\hline & -391 & 0.6 & 0.4 & 1.1 & 0.7 & 0.4 \\
\hline & -401.5 & 0.4 & 0.6 & 0.4 & 0.5 & 0.1 \\
\hline
\end{tabular}


APPENDIX B: Carbonate rock densities from core GW-722

$\begin{array}{ll}\text { Depth (ft) } & \text { Density } \\ 76.5 & \left(\mathrm{~g} / \mathrm{cm}^{3}\right) \\ 84.3 & 2.44 \\ 89.3 & 2.65 \\ 93.9 & 2.52 \\ 103.5 & 2.84 \\ 114.5 & 2.74 \\ 126.0 & 2.95 \\ 144.0 & 2.84 \\ 152.9 & 2.67 \\ 160.0 & 2.95 \\ 171.0 & 2.47 \\ 186.5 & 2.59 \\ 197.0 & 2.75 \\ 200.0 & 2.49 \\ 223.0 & 2.75 \\ 233.0 & 2.78 \\ 241.5 & 2.31 \\ 260.5 & 2.92 \\ 278.0 & 2.60 \\ 286.5 & 2.68 \\ 293.3 & 2.38 \\ 312.2 & 2.57 \\ 322.0 & 2.61 \\ 332.0 & 2.67 \\ 344.3 & 2.70 \\ 361.8 & 2.72 \\ 374.3 & 2.76 \\ 381.0 & 2.81 \\ 398.0 & 2.83 \\ 412.5 & 2.56 \\ 426.0 & 2.56 \\ 444.3 & 2.61 \\ 463.5 & 2.59 \\ 488.5 & 2.77 \\ 498.5 & 2.68 \\ 509.0 & 2.70 \\ 521.0 & 2.62 \\ 523.5 & 2.65 \\ 535.0 & 2.69 \\ 550.5 & 2.38 \\ 567.5 & 2.61 \\ 580.5 & 2.74 \\ 591.5 & 2.54 \\ 600.0 & 2.52 \\ 603.9 & \end{array}$




\section{APPENDIX C}

Petrographic analyses for the Maynardville Limestone.

Percentages based on 300 point counts on a $1.5 \mathrm{~mm}$ X $1.5 \mathrm{~mm}$ grid.

\section{WELL GW-135}

Depth: $731.5 \mathrm{ft}$

Zone 6

Vuggy dolomite
$1.3 \%$
Clay
$97.0 \%$
Dolomite (ferroan)
$1.6 \%$
Porosity (mesoporosity; solution enlarged; moldic)

Depth: $745 \mathrm{ft}$

Zone 6

Vuggy, dolomite

\section{$5.3 \% \quad$ Clay}

$2.3 \% \quad$ Sparite (fine-grained)

91.0\% Dolomite (ferroan)

1.3\% Porosity (micro-mesoporosity; solution enlarged; moldic)

Depth: $769 \mathrm{ft}$

Zone 6

Vuggy, dolomite
$1.0 \%$
Clay.

$0.6 \%$

$88.0 \%$

Sparite (fine-grained, within vugs)

$10.3 \%$

Dolomite (mostly ferroan, nonferroan in vugs and fractures)

Porosity (small megaporosity; solution enlarged, vuggy)

Depth: $808 \mathrm{ft}$

Zone 5

Oosparite, dolomitic

$0.3 \%$

$20.0 \%$

Pyrite

$57.0 \%$

Micrite

$22.3 \%$

Sparite (fine-grained, drusy)

$0.3 \%$

Dolomite (ferroan, commonly core ooids)

Porosity (solution enlarged, moldic; rare intercrystalline) 
Depth: $817.5 \mathrm{ft}$

Zone 5

Pel, biosparite

26.6\%。 Clay

$0.6 \% \quad$ Pyrite

19.6\% Micrite

22.6\% Sparite (fine-grained)

30.3\% Dolomite (ferroan)

0\% Porosity

Depth: $837.5 \mathrm{ft}$

Zone 5

Oosparite

$\begin{array}{ll}0.3 \% & \text { Clay } \\ 36.0 \% & \text { Micrite } \\ 51.6 \% & \text { Sparite (fine-grained) } \\ 12.0 \% & \text { Dolomite (ferroan) } \\ 0 \% & \text { Porosity }\end{array}$

Depth: $882.5 \mathrm{ft}$

Zone 4

Sparite

$\begin{array}{ll}34.3 \% & \text { Micrite } \\ 49.0 \% & \text { Sparite (fine-grained) } \\ 16.6 \% & \text { Dolomite (ferroan) } \\ 0 \% & \text { Porosity }\end{array}$

Depth: $953 \mathrm{ft}$

Zone 4

Calcareous dolomite

$\begin{array}{ll}2.0 \% & \text { Pyrite } \\ 13.6 \% & \text { Micrite } \\ 30.6 \% & \text { Sparite (fine-grained) } \\ 53.6 \% & \text { Dolomite (ferroan) } \\ 0 \% & \text { Porosity }\end{array}$

Depth: $1006 \mathrm{ft}$

Zone 3

Oosparite

$2.6 \%$

Clay (associated with stylolites)

$34.0 \%$

Micrite

$47.3 \%$

Sparite (fine-grained)

$16.0 \%$

$0 \%$

Dolomite (ferroan, cores ooids)

Porosity 
Depth: $1044 \mathrm{ft}$

Zone 3

Micrite

$17.6 \%$

$39.6 \%$

Clay (chloritic, associated with thrombolitic laminations)

$30.6 \% \quad$ Sparite (fine-grained)

12.0\% Dolomite (ferroan)

$0 \% \quad$ Porosity

Depth: $1133 \mathrm{ft}$

Zone 2

Micrite

$2.6 \%$

$51.3 \%$

Clay

$35.0 \%$

Micrite

$11.0 \%$

Sparite (fine-grained)

$0 \%$

Dolomite (ferroan)

Porosity

Depth: $1198 \mathrm{ft}$

Zone 2

Micrite

1.0\% Clay (chloritic)

0.3\% Pyrite

$53.6 \% \quad$ Micrite

$37.6 \% \quad$ Sparite (fine-grained)

$0.6 \%$

$6.3 \%$

Sparite (coarse-grained; infilling pores)

$0.3 \%$

Dolomite

Porosity (microporosity; fenestral)

\section{WELL GW-137}

Depth: $131.5 \mathrm{ft}$

Zone 3

Pelmicrite

$\begin{array}{ll}11.3 \% & \text { Clay } \\ 65.3 \% & \text { Micrite } \\ 21.6 \% & \text { Sparite (fine-grained) } \\ 1.6 \% & \text { Dolomite } \\ \text { rare } & \text { Porosity (moldic) }\end{array}$


Depth: $218.5 \mathrm{ft}$

Zone 2

Pelmicrite
$2.6 \%$
Clay (chloritic)
$1.6 \%$
$52.0 \%$
Hematite (after pyrite)
$35.6 \%$
Micrite
$5.0 \%$
Sparite (fine-grained, drusy)
$3.0 \%$
Sparite (coarse-grained, infilling veins and vugs)
Porosity (small mesoporosity associated with dissolution of pyrite crystals; cement-filled fractures and vugs)

\section{WELL GW-138}

Depth: $432.5 \mathrm{ft}$

Copper Ridge Dolomite

Vuggy Dolomite

$2.0 \%$

$4.3 \%$

Clay

$78.6 \%$

Sparite (fine-grained, lines vug walls)

$15.0 \%$

Dolomite (ferroan)

Porosity (Mostly solution enlarged small megapore vugs with lesser amounts of solution enlarged fracture and small mesopore moldic porosity)

Depth: $483 \mathrm{ft}$

Zone 6

Vuggy dolomite

$\begin{array}{ll}0.3 \% & \text { Clay } \\ 95.3 \% & \text { Dolomite (ferroan) }\end{array}$

$4.3 \%$

Porosity (mostly solution enlarged small mesopore moldic porosity with lesser amounts of solution enlarged large mesopore vugs and fracture porosity)

Depth: $539 \mathrm{ft}$

Zone 6

Calcareous dolomite
$30.9 \%$
Micrite
$1.3 \%$
Sparite (fine-grained)
$67.6 \%$
$0 \%$
Dolomite (ferroan)
Porosity 
Depth: $560 \mathrm{ft}$

Zone 5

Bio, pelmicrite

$\begin{array}{ll}87.9 \% & \text { Micrite } \\ 1.3 \% & \text { Sparite (fine-grained) } \\ 1.0 \% & \text { Sparite (coarse-grained, infilling vugs and veins) } \\ 9.6 \% & \text { Dolomite } \\ 0 \% & \text { Porosity }\end{array}$

Depth: $567 \mathrm{ft}$

Zone 5

Oosparite

$13.6 \%$

Micrite

$49.3 \%$

$36.6 \%$

Sparite (fine-grained)

$0.3 \%$

Dolomite

Porosity (solution enlarged moldic porosity; dissolution of dolomite crystals coring ooids)

Depth: $626 \mathrm{ft}$

Zone 4

Dolomite

$\begin{array}{ll}1.6 \% & \text { Pyrite } \\ 7.0 \% & \text { Sparite (fine-grained) } \\ 0.3 \% & \text { Sparite (coarse-grained) } \\ 91.0 \% & \text { Dolomite } \\ 0 \% & \text { Porosity }\end{array}$

Depth: $658 \mathrm{ft}$

Zone 4

Oo, pelsparite
$0.3 \%$
Pyrite
$0.3 \%$
Clay (associated with stylolites)
$29.0 \%$
Micrite
$63.0 \%$
Sparite (fine-grained)
$0.6 \%$
Sparite (coarse-grained)
$6.3 \%$
Dolomite
$0 \%$ Porosity 
Depth: $678 \mathrm{ft}$

Zone 4

Dolomitic pelsparite

$\begin{array}{ll}1.3 \% & \text { Clay (associated with stylolites) } \\ 7.0 \% & \text { Gypsum (vein filling) } \\ 22.6 \% & \text { Micrite } \\ 43.3 \% & \text { Sparite (fine-grained) } \\ 25.6 \% & \text { Dolomite } \\ 0 \% & \text { Porosity }\end{array}$

Depth: $708.5 \mathrm{ft}$

Zone 4

Dolomite

$\begin{array}{ll}3.3 \% & \text { Gypsum (vein filling) } \\ 1.3 \% & \text { Micrite } \\ 8.3 \% & \text { Sparite (fine-grained) } \\ 87.0 \% & \text { Dolomite (ferroan and bladed) } \\ 0 \% & \text { Porosity }\end{array}$

Depth: $735 \mathrm{ft}$

Zone 3

Oo, pelsparite

$\begin{array}{ll}3.0 \% & \text { Clay (associated with stylolites) } \\ 31.3 \% & \text { Micrite } \\ 45.3 \% & \text { Sparite (fine-grained) } \\ 5.3 \% & \text { Sparite (coarse-grained) } \\ 15.0 \% & \text { Dolomite (ferroan) } \\ 0 \% & \text { Porosity }\end{array}$

Depth: $785 \mathrm{ft}$

Zone 3

Dolomitic sparite

$2.0 \%$

$11.0 \%$

Clay

$51.3 \%$

Micrite

$0.6 \%$

$35.0 \%$

Sparite (fine-grained)

Sparite (coarse-grained)

rare

Dolomite (ferroan)

$0 \%$

Glauconite

Porosity 
Depth: $860 \mathrm{ft}$

Zone 2

Calcareous dolomite

$\begin{array}{ll}6.3 \% & \text { Clay } \\ 0.3 \% & \text { Glauconite } \\ 0.3 \% & \text { Pyrite } \\ 11.0 \% & \text { Micrite } \\ 16.6 \% & \text { Sparite (fine-grained) } \\ 2.3 \% & \text { Sparite (coarse-grained, lines vugs) } \\ 60.0 \% & \text { Dolomite (ferroan) } \\ 3.0 \% & \text { Porosity (small megapore vugs) }\end{array}$

Depth: $945 \mathrm{ft}$

Zone 2

Pelmicrite
$1.3 \%$
Clay
$0.3 \%$
Barite (lining vug walls)
$57.6 \%$
Micrite
$21.3 \%$
Sparite (fine-grained, drusy, infilling vug edges and veins)
$18.0 \%$
Dolomite (ferroan)
$1.3 \%$
Porosity (solution enlarged large mesopore vugs and fracture porosity) 


\section{DISTRIBUTION}

DEPARTMENT OF ENERGY

P. A. Hoffman

L. M. Sparks

HEALTH, SAFETY, ENVIRONMENT, AND

ACCOUNTABILITY ORGANIZATION

W. P. Carlton

W. K. Jago

S. B. Jones

L. O. Vaughan

File-GWPP-RC (4)

ENVIRONMENTAL RESTORATION PROGRAM

H. L. King

C. S. Walker

ENVIRONMENTAL SCIENCES DIVISION

R. B. Dreier

D. D. Huff

C. T. Rightmire

D. B. Watson
TDEC/DOE-Q

Robert Benfield (3)

UNIVERSITY OF NEVADA, RENO

P. M. Goldstrand (3)

L. A. Shevenell

APPALACHIAN STATE UNIVERSITY

L. S. Menefee

SAIC

W. P. Kegley/D. Moss

CDM FEDERAL PROGRAMS

M/ Leslie/C. Lutz

A. K. Lee/DOE-OSTI (2)

Y-12 Central Files 